Article

\title{
Thermal Decomposition Behavior and Thermal Safety of Nitrocellulose with Different Shape $\mathrm{CuO}$ and $\mathrm{Al} / \mathrm{CuO}$ Nanothermites
}

\author{
Ergang Yao ${ }^{1}$, Ningning Zhao ${ }^{2, *}$, Zhao Qin ${ }^{1}$, Haixia Ma ${ }^{3}$, Haijian $\mathrm{Li}^{1}{ }^{1}, \operatorname{Siyu} \mathrm{Xu}^{1}{ }^{1}, \operatorname{Ting}_{\mathrm{An}}{ }^{1}$, \\ Jianhua $\mathrm{Yi}^{1}$ and Fengqi Zhao ${ }^{1, *}$ \\ 1 Science and Technology on Combustion and Explosion Laboratory, Xi'an Modern Chemistry Research \\ Institute, Xi'an 710065, China; yaoerg@126.com (E.Y.); qzhao87@163.com (Z.Q.); h.j.Li@outlook.com (H.L.); \\ xusy99@163.com (S.X.); anting715@163.com (T.A.); npecc_yjh2819@163.com (J.Y.) \\ 2 School of Science, Xi'an University of Technology, Xi'an 710054, China \\ 3 School of Chemical Engineering, Northwest University, Xi'an 710069, China; mahx@nwu.edu.cn \\ * Correspondence: zhaonn@xaut.edu.cn (N.Z.); npecc@163.com (F.Z.)
}

Received: 15 March 2020; Accepted: 7 April 2020; Published: 11 April 2020

\begin{abstract}
Bamboo leaf-like $\mathrm{CuO}(\mathrm{b})$ and flaky-shaped $\mathrm{CuO}(\mathrm{f})$ were prepared by the hydrothermal method, and then combined with $\mathrm{Al}$ nanoparticles to form $\mathrm{Al} / \mathrm{CuO}(\mathrm{b})$ and $\mathrm{Al} / \mathrm{CuO}(\mathrm{f})$ by the ultrasonic dispersion method. The phase, composition, morphology, and structure of the composites were characterized by X-ray powder diffraction (XRD), transmission electron microscopy (TEM), scanning electron microscopy (SEM), and energy scattering spectrometer (EDS). The compatibility of CuO, $\mathrm{Al} / \mathrm{CuO}$ and nitrocellulose (NC) was evaluated by differential scanning calorimetry (DSC). The effects of $\mathrm{CuO}$ and $\mathrm{Al} / \mathrm{CuO}$ on the thermal decomposition of $\mathrm{NC}$ were also studied. The results show that the thermal decomposition reactions of $\mathrm{CuO}-\mathrm{NC}$ composite, $\mathrm{Al} / \mathrm{CuO}-\mathrm{NC}$ composite, and $\mathrm{NC}$ follow the same kinetic mechanism of Avrami-Erofeev equation. In the cases of $\mathrm{CuO}$ and $\mathrm{Al} / \mathrm{CuO}$, they could promote the $\mathrm{O}-\mathrm{NO}_{2}$ bond cleavage and secondary autocatalytic reaction in condensed phase. The effects of these catalysts have some difference in modifying the thermolysis process of NC due to the microstructures of $\mathrm{CuO}$ and the addition of $\mathrm{Al}$ nanopowders. Furthermore, the presence of $\mathrm{Al} / \mathrm{CuO}(\mathrm{f})$ can make the $\mathrm{Al} / \mathrm{CuO}(\mathrm{f})-\mathrm{NC}$ composite easier to ignite, whereas the composites have strong resistance to high temperature. Compatibility and thermal safety analysis showed that the $\mathrm{Al} / \mathrm{CuO}$ had good compatibility with NC and it could be used safely. This contribution suggests that $\mathrm{CuO}$ and $\mathrm{Al} / \mathrm{CuO}$ played key roles in accelerating the thermal decomposition of NC.
\end{abstract}

Keywords: nanoenergetic material; compatibility; nonisothermal reaction kinetics; thermal safety; catalytic action

\section{Introduction}

Nanosize metal oxides exhibit excellent electrical, optical, magnetic, and catalytic properties, because they have high specific surface area and surface energy, and active sites. Therefore, the preparation and application of nanosize metal oxides have attracted widespread attention. Recently, nanosize $\mathrm{CuO}$ has been extended studies for the potential applications in ion batteries [1,2], gas sensors [3], catalysts [4,5], magnetoelectric effects [6], etc. It has become the typical representative of nanosize transition metal oxides. In the field of explosives and solid propellants [7], nanosize $\mathrm{CuO}$, as an important catalyst, has been applied for promoting combustion. There are a lot of reports regarding the catalytic effects of nanometal oxides to the main components of solid propellants [8]. $\mathrm{CuO}$ can decrease the decomposition peak temperature and activity energy of ammonium perchlorate (AP), and increase the decomposition reaction rate and releasing heat of AP $[9,10]$. When adding 
nanosize $\mathrm{CuO}$ to solid propellant formulations, it can increase the burning rate and decrease the pressure index [11].

The temperature of thermite reaction between $\mathrm{CuO}$ and $\mathrm{Al}$ can reach $2840 \mathrm{~K}$, and its volume energy density is approximately three times higher than TNT [12]. The theoretical combustion heat of the $\mathrm{Al} / \mathrm{CuO}$ thermite can reach to $3324.45 \mathrm{~kJ} \cdot \mathrm{kg}^{-1}$, which is higher than that of $\mathrm{Al} / \mathrm{ZnO}\left(3256.33 \mathrm{~kJ} \cdot \mathrm{kg}^{-1}\right)$, $\mathrm{Al} / \mathrm{CdO}\left(2045.85 \mathrm{~kJ} \cdot \mathrm{kg}^{-1}\right)$, and $\mathrm{Al} / \mathrm{Bi}_{2} \mathrm{O}_{3}\left(1511.26 \mathrm{~kJ} \cdot \mathrm{kg}^{-1}\right)$. When the $\mathrm{Al} / \mathrm{CuO}$ nanothermites are used as a combustion catalyst, it can effectively improve the combustion performance of solid propellants due to the excellent characteristics of high energy density, high burning rate, high temperature of reaction product, and no need for oxygen during the combustion of $\mathrm{Al} / \mathrm{CuO}$ nanothermites [13-15].

As a main energetic component, nitrocellulose (NC) with a nitrogen amount higher than $12 \%$ is widely used for gun and rocket propellants [16-19]. However, the applications of NC are extremely limited, due to the low burning temperature, the high impact sensitivity, the high friability, and the low density $[20,21]$. Additionally, the exothermic degradation of NC exists the potential hazard during the preparation, storage, and use [22,23]. It has been extensively studied experimentally and theoretically for revealing the pyrolysis mechanism and improving the energetic characteristics [24]. As an important research means, thermal analysis technology, such as differential scanning calorimetry (DSC) and thermogravimetric (TG), play an important role in obtaining the thermal decomposition performance of energetic materials. Additionally, the kinetic analysis that can obtain the kinetic parameters (pre-exponential factor, activation energy, and reaction model) by using DSC or TG data are also very useful for understanding the thermal decomposition reaction mechanism $[25,26]$. Accordingly, the non-isothermal kinetics approach of energetic materials based on the thermal analysis technique is employed to obtain the kinetic parameters of the thermal decomposition.

It is extremely importance that all the materials in the system are compatible due to the particularity of the energetic material itself. This means that they do not interact chemically and physically with each other in the energetic materials system. Poor compatibility might give rise to safety hazards in handing and deteriorated performance. Therefore, if we want to apply a novel substance or material to explosives, propellants, and pyrotechnics system, the first issue that must be considered is the compatibility of the new material with each other components. Various additives have been mixed with $\mathrm{NC}$ for either enhancing its stability or improving its pyrolysis properties. Current research shows that the additive, such as nanometal oxide, can accelerated the rupture of the $\mathrm{O}_{-} \mathrm{NO}_{2}$ bonds [27] of $\mathrm{NC}$ and generated the $\mathrm{NO}_{2}$ gas. A large amount of $\mathrm{NO}_{2}$ can be adsorbed, which further enhances the secondary autocatalytic reaction of $\mathrm{NC}$, due to the high specific surface area of $\mathrm{Cr}_{2} \mathrm{O}_{3}$ nanoparticles [28]. The DSC method is one of the most commonly used methods, not only for evaluating the chemical compatibility between components in the mixtures system at high temperatures, but also for investigating the thermal safety characteristic and the thermal decomposition behavior of the NC with catalyst [29-35].

In this study, the Bamboo leaf-like $\mathrm{CuO}(\mathrm{b})$ and flaky-shaped $\mathrm{CuO}(\mathrm{f})$ were prepared by the hydrothermal method. The differential scanning calorimetry (DSC) was used to evaluate the compatibility between $\mathrm{CuO}, \mathrm{Al} / \mathrm{CuO}$, and $\mathrm{NC}$. The thermal behavior and nonisothermal decomposition kinetics of the different $\mathrm{CuO}$ and $\mathrm{Al} / \mathrm{CuO}$ to $\mathrm{NC}$ was investigated and the thermal decomposition kinetic mechanism function was explored. The DSC method evaluated the thermal safety characteristic of the $\mathrm{NC}$ composite system with $\mathrm{CuO}$ or $\mathrm{Al} / \mathrm{CuO}$ as catalyst, which has the advantages of cheap, small quantity of sample required, and the capability of quickly select samples with better thermal decomposition performance.

\section{Experimental}

\subsection{Materials}

$\mathrm{CuCl}_{2} \cdot 2 \mathrm{H}_{2} \mathrm{O}, \mathrm{NaOH}$ and anhydrous ethanol were purchased from Xilong Chemical Reagent Co. (Guangzhou, China), and they were all of analytical grade. Al nanopowders (chemical grade), approximately $50 \mathrm{~nm}$ in average diameter, was purchased from Jiaozuo Banlv Nano Material 
Engineering Co. Ltd. (Jiaozuo, China). NC $(12.6 \% \mathrm{~N})$ was obtained from Xi'an Modern Chemistry Research Institute (Xi'an, China). All of the chemicals were used without further purification. The deionized water was used in entire experiment course.

\subsection{Preparation of Bamboo Leaf-like $\mathrm{CuO}(b)$ and $\mathrm{Al} / \mathrm{CuO}(\mathrm{b})$}

$0.47 \mathrm{~g}$ of $\mathrm{CuCl}_{2} \cdot 2 \mathrm{H}_{2} \mathrm{O}$ was dissolved in $20 \mathrm{~mL}$ deionized water, and then $10 \mathrm{~mL} \mathrm{NaOH}$ solution $\left(1 \mathrm{~mol} \cdot \mathrm{L}^{-1}\right)$ were added dropwise. After stirring for $30 \mathrm{~min}$, the mixture was poured into a hydrothermal reaction vessel and reacted at $120^{\circ} \mathrm{C}$ for $8 \mathrm{~h}$. After the reaction is completed and natural cooling afterwards, the precipitate was separated and washed with anhydrous ethanol and deionized water several times. Subsequently, the precipitate was dried in an oven at $60^{\circ} \mathrm{C}$. Finally, the bamboo leaf-like $\mathrm{CuO}(\mathrm{b})$ was obtained.

After the $\mathrm{CuO}(\mathrm{b})$ were mixed up with $\mathrm{Al}$ nanopowders according to the mole rate of 1.33:1 for $\mathrm{Al}: \mathrm{CuO}[36,37]$, the $\mathrm{Al} / \mathrm{CuO}(\mathrm{b})$ nanothermite was prepared by the ultrasonic dispersion method.

\subsection{Preparation of Flaky-shaped $\mathrm{CuO}(f)$ and $\mathrm{Al} / \mathrm{CuO}(f)$}

$0.47 \mathrm{~g}$ of $\mathrm{CuCl}_{2} \cdot 2 \mathrm{H}_{2} \mathrm{O}$ was dissolved in $20 \mathrm{~mL}$ deionized water, and then $10 \mathrm{~mL} \mathrm{NaOH}$ solution $\left(1 \mathrm{~mol} \cdot \mathrm{L}^{-1}\right)$ was added dropwise. After stirring for $30 \mathrm{~min}$, the mixture was poured into a hydrothermal reaction vessel and reacted at $180{ }^{\circ} \mathrm{C}$ for $16 \mathrm{~h}$. After the reaction is completed and natural cooling afterwards, the precipitate was separated and then washed with anhydrous ethanol and deionized water for several times. Subsequently, the precipitate was dried in an oven at $60{ }^{\circ} \mathrm{C}$. Finally, the flaky-shaped $\mathrm{CuO}(\mathrm{f})$ was obtained.

The $\mathrm{Al} / \mathrm{CuO}(\mathrm{f})$ nanothermite was prepared by the ultrasonic dispersion method after the $\mathrm{CuO}(\mathrm{f})$ were mixed up with $\mathrm{Al}$ nanopowders according to the mole rate of $1.33: 1$ for $\mathrm{Al}: \mathrm{CuO}[36,37]$.

\subsection{Samples Characterization}

An FEI Quanta 400 (FEI Co., Hillsboro, OR, USA) field-emission environment scanning electron microscope (SEM) characterized the morphology and structure of the sample. The acceleration voltage was $30 \mathrm{kV}$ and current was $4 \mathrm{~A}$. OXFORD INCAIE350 energy-dispersive X-ray spectroscopy (EDS) from OXFORD Instruments INC (Oxford, UK) was used to roughly examine the composition of the sample. The discharge voltage was $4-10 \mathrm{kV}$ and the distance between the electrodes was exactly $1 \mathrm{~mm}$. The morphology and size of the sample were investigated via transmission electron microscopy (TEM) and high-resolution TEM using HITACHI H-7650B (Tokyo, Japan). The operating voltage was $80 \mathrm{kV}$ and resolution was $0.2 \mathrm{~nm}$ (lattice image). The purity and phase structure of the sample were confirmed by powder X-ray diffraction (XRD) analysis on a Rigaku D/MAX-3C (Tokyo, Japan) X-ray powder Diffractometer. The radiation source was $\mathrm{Cu} K_{\alpha}(\lambda=1.5418 \AA)$ at $40 \mathrm{kV}$ and $40 \mathrm{~mA}$, and the range of $2 \theta$ was $10^{\circ}$ to $80^{\circ}$.

\subsection{Measurement of Thermal Decomposition Properties and Compatibility}

The thermal behavior and kinetic analysis of the samples were performed while using differential scanning calorimetry (DSC). The effects of $\mathrm{CuO}$ and $\mathrm{Al} / \mathrm{CuO}$ on the thermal decomposition properties of nitrocellulose (NC) were investigated using DSC (Q2000, TA Co., New Castle, DE, USA) under an $\mathrm{N}_{2}$ atmosphere at a flow rate of $50 \mathrm{~mL} \cdot \mathrm{min}^{-1}$. The test temperature range was room temperature to $300{ }^{\circ} \mathrm{C}$, and the heating rate was $5.0,10.0,15.0,20.0,25.0$, and $30.0^{\circ} \mathrm{C} \cdot \mathrm{min}^{-1}$. The mass of each sample was about $0.22 \mathrm{mg}$ and the sample cell is an aluminum crucible. The $\mathrm{CuO}-\mathrm{NC}$ and $\mathrm{Al} / \mathrm{CuO}-\mathrm{NC}$ composites were obtained by physical mixing in an agate mortar at room temperature. The mass ratio of $\mathrm{CuO}$ : $\mathrm{NC}$ for the $\mathrm{CuO}-\mathrm{NC}$ composites, and $\mathrm{Al} / \mathrm{CuO}$ : $\mathrm{NC}$ for the $\mathrm{Al} / \mathrm{CuO}-\mathrm{NC}$ composites was 1:19.

The DSC thermal analysis method was used to assess the compatibility of different $\mathrm{CuO}$ and $\mathrm{Al} / \mathrm{CuO}$ nanothermites with NC. The results come from the above-mentioned DSC test at the heating rate of $10.0^{\circ} \mathrm{C} \cdot \mathrm{min}^{-1}$. The evaluation standard for compatibility of ingredients can refer to $[29,30]$. 


\section{Results and Discussion}

\subsection{Morphology and Structure}

Figure 1 shows the SEM images of $\mathrm{CuO}$ prepared at different reaction temperatures. When the reaction temperature is $80{ }^{\circ} \mathrm{C}$, the obtained $\mathrm{CuO}$ is spindle shaped in the whole, as shown in Figure 1 a. That is thick in the middle and thin in both ends. There are many stripe protrusions in the middle spindle shaped structure, and the ends of spindle shaped structure are curly. When the reaction temperature is $120^{\circ} \mathrm{C}$, the obtained $\mathrm{CuO}$ is bamboo leaf-shaped (Figure $1 \mathrm{~b}$ ). There are a few protrusions on the surface, and the leaves are thin. When the reaction temperature is $160^{\circ} \mathrm{C}$, the obtained $\mathrm{CuO}$ is in the boat form (Figure 1c). Its size becomes smaller than the structure that is shown in Figure 1a,b. When the reaction temperature is $160^{\circ} \mathrm{C}$, the size of obtained $\mathrm{CuO}$ is the smallest, and there are raised fragments on the surface (Figure 1d). These experimental results show that the size of the obtained $\mathrm{CuO}$ gradually decreases with the temperature increases and its morphology also obviously changed.

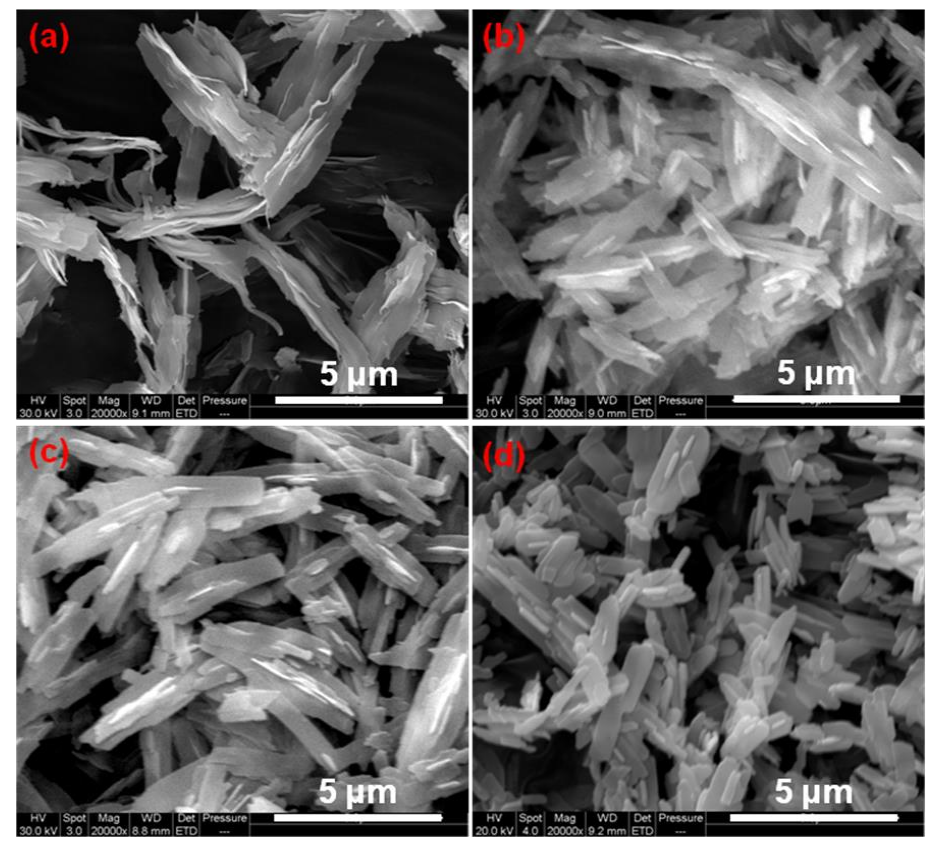

Figure 1. Scanning electron microscope (SEM) images of the as-prepared $\mathrm{CuO}$ with different reaction temperatures. (a) $80{ }^{\circ} \mathrm{C}$; (b) $120^{\circ} \mathrm{C}$; (c) $160{ }^{\circ} \mathrm{C}$; and, (d) $180{ }^{\circ} \mathrm{C}$.

Figure 2 shows the SEM images of $\mathrm{CuO}$ prepared at $120^{\circ} \mathrm{C}$ with different reaction times. When the reaction time is $2 \mathrm{~h}$, the structure of obtained $\mathrm{CuO}$ is similar to the "shrimp head" with multiple curled "shrimp beard" at the end, as shown in Figure 2a. When the reaction time is $4 \mathrm{~h}$, most of the obtained $\mathrm{CuO}$ structures are bamboo leaf-shaped (Figure 2b). There are a lot of protrusions on the surface, and the leaves are thin. When the reaction time is $8 \mathrm{~h}$, the obtained $\mathrm{CuO}$ is also bamboo leaf-shaped (Figure 2c). There are a few protrusions at the middle region of surface, and the two ends are flaky-shaped. As the reaction time extend to $12 \mathrm{~h}$ (Figure 2d) or $16 \mathrm{~h}$ (Figure 2e), the morphology of the obtained $\mathrm{CuO}$ is found not significantly different from the $\mathrm{CuO}$ that is shown in Figure 2c. However, the agglomeration degree of $\mathrm{CuO}$ is obviously increased. This shows that the morphology of the obtained $\mathrm{CuO}$ is changed obviously with the extension of the reaction time. As the reaction time exceeds $8 \mathrm{~h}$, the morphology is changed very little and it has significant aggregate. 


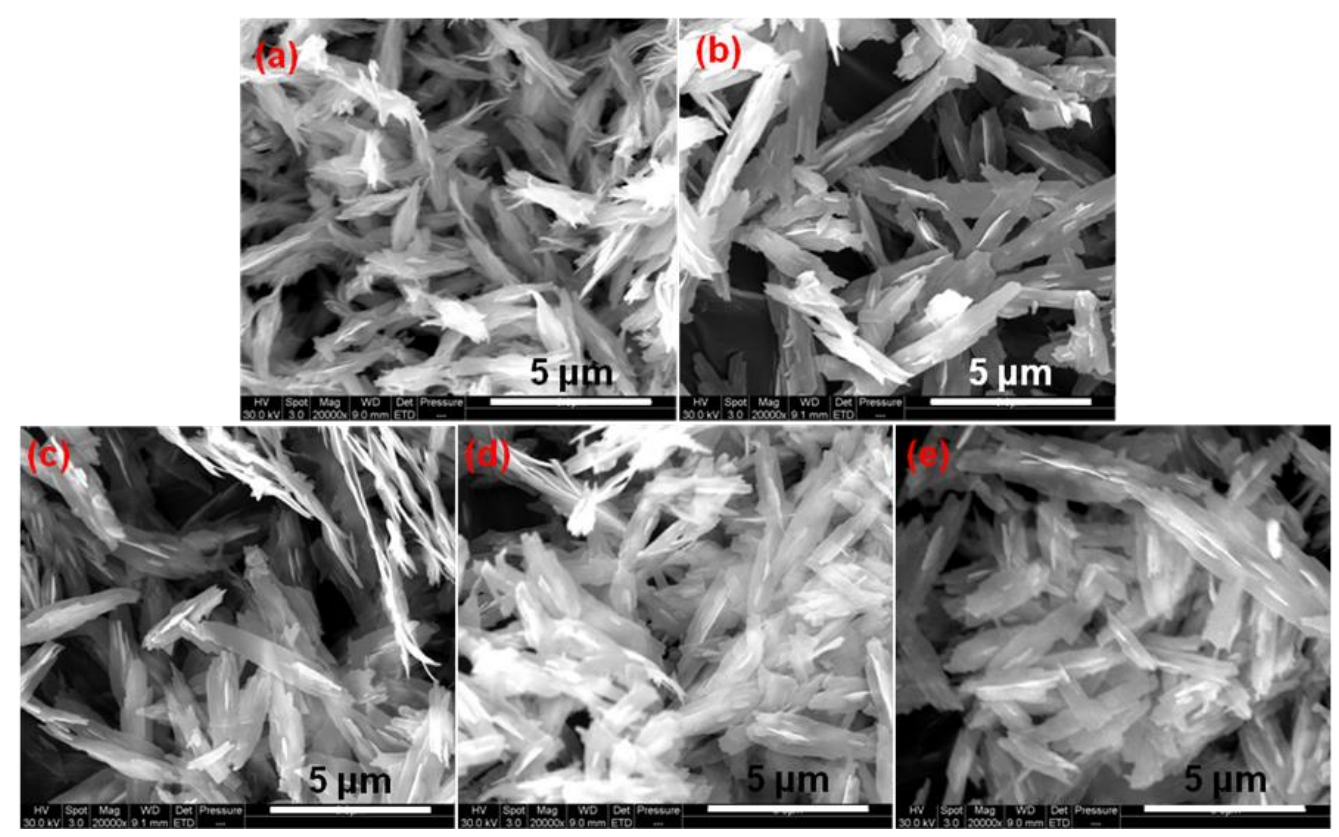

Figure 2. SEM images of the as-prepared $\mathrm{CuO}$ at $120{ }^{\circ} \mathrm{C}$ with different reaction times. (a) $2 \mathrm{~h}$; (b) $4 \mathrm{~h}$; (c) $8 \mathrm{~h}$; (d) $12 \mathrm{~h}$; and, (e) $16 \mathrm{~h}$.

TEM and SEM analysis were performed to probe the elemental composition and morphology of the bamboo leaf-like $\mathrm{CuO}(\mathrm{b})$ obtained by reacting at $120^{\circ} \mathrm{C}$ for $8 \mathrm{~h}$ and corresponding $\mathrm{Al} / \mathrm{CuO}$ nanothermites, the results are exhibited in Figure 3. It can be seen from the TEM image of bamboo leaf-like $\mathrm{CuO}(\mathrm{b})$ (Figure 3a) that the maximum leaf of $\mathrm{CuO}(\mathrm{b})$ is about $1.6 \mu \mathrm{m}$ in length, $300 \mathrm{~nm}$ in width, and $57 \mathrm{~nm}$ in thickness. The leaf surface is not smooth. There are many folds and a few leaves have protrusions in the middle. The protrusion is about $25 \mathrm{~nm}$ wide and about $90 \mathrm{~nm}$ long. Figure $3 \mathrm{~b}$ is a high-resolution transmission electron microscope (HRTEM) image of the $\mathrm{CuO}$ and its corresponding fast Fourier transform (FFT) pattern. It is found that the lattice fringes with a lattice distance of $0.27 \mathrm{~nm}$ appeared at this position, corresponding to the (110) plane. Figure $3 \mathrm{c}$ is the selected area electron diffraction (SAED) image of the $\mathrm{CuO}$ sample. From Figure 3c, one can see that there are some clear scattered points, which indicate that the $\mathrm{CuO}$ leaves are single crystal structure and well-crystallized. Figure 3d is the SEM image of $\mathrm{Al} / \mathrm{CuO}$ nanothermites. The spherical $\mathrm{Al}$ nanopowders and bamboo leaf-like $\mathrm{CuO}$ stick to each other, as shown in Figure 3d. Additionally, there are some agglomerate for the Al nanopowders because of their small size.

We present their SEM images and energy-dispersive X-ray spectroscopy (EDS) patterns to analyze the morphology and composition of the above flaky-shaped $\mathrm{CuO}(\mathrm{f})$ and its corresponding $\mathrm{Al} / \mathrm{CuO}(\mathrm{f})$ nanothermites samples, as shown in Figure $4 a-d$. It can be seen from Figure $4 a$ that the shape of as-prepared $\mathrm{CuO}$ is flaky-shaped, the surface is not smooth, and it is covered with depressions and protrusions. Figure $4 \mathrm{c}$ is the SEM image of $\mathrm{Al} / \mathrm{CuO}(\mathrm{f})$ nanothermites sample obtained by ultrasonic dispersion method with $\mathrm{Al}$ nanopowders and flaky-shaped $\mathrm{CuO}(\mathrm{f})$. Some spherical aluminum nanoparticles with smaller particle sizes are coated on the surface of some $\mathrm{CuO}$ fragments, as shown in Figure 4c. The self-agglomeration phenomenon of the Al nanopowders is weak due to the ultrasonic effect. The EDS and XRD results of flaky-shaped $\mathrm{CuO}(\mathrm{f}$ ) (Figures $4 \mathrm{~b}$ and $5 \mathrm{~d}$ ) show that the sample obtained by the hydrothermal method is the pure $\mathrm{CuO}$ phase. Figure $4 \mathrm{~d}$ is the EDS pattern of the $\mathrm{Al} / \mathrm{CuO}$ (f) nanothermites. In combination with its XRD characterization results (Figure $5 \mathrm{c}$ ), it can be obtained that the $\mathrm{Al} / \mathrm{CuO}(\mathrm{f})$ sample is a mixture of $\mathrm{Al}$ and $\mathrm{CuO}$. Because there is no other characteristic diffraction peaks, except the $\mathrm{Al}$ and $\mathrm{CuO}$. Figure 4e is a TEM image for the flaky-shaped $\mathrm{CuO}(\mathrm{f})$. It can be seen that the fragments of flaky-shaped $\mathrm{CuO}(\mathrm{f})$ are irregular in shape and have wrinkles on the surface. The thickness is about $90 \mathrm{~nm}$ and the dispersion is good. From the enlarged view of the flaky-shaped 
$\mathrm{CuO}(\mathrm{f})$ (Figure 4f), we can see that the folds on the fragments are clear. The largest fragment in size is approximately $0.75 \mu \mathrm{m}$ wide and about $2.5 \mu \mathrm{m}$ long, and the protrusions on the surface are about $0.13 \mu \mathrm{m}$ wide. Figure $4 \mathrm{~g}$ is a HRTEM image of flaky-shaped $\mathrm{CuO}(\mathrm{f})$ and its corresponding FFT pattern (insert). It is found that the lattice fringes with a lattice distance of $0.27 \mathrm{~nm}$ appeared at this position, corresponding to the (110) plane. Figure $4 \mathrm{~h}$ is a SAED pattern of the flaky-shaped $\mathrm{CuO}(\mathrm{f})$ sample. The clear scattered points presented in Figure $4 \mathrm{~h}$ indicate that the flaky-shaped $\mathrm{CuO}(\mathrm{f})$ is a single crystal structure with well-crystallized.

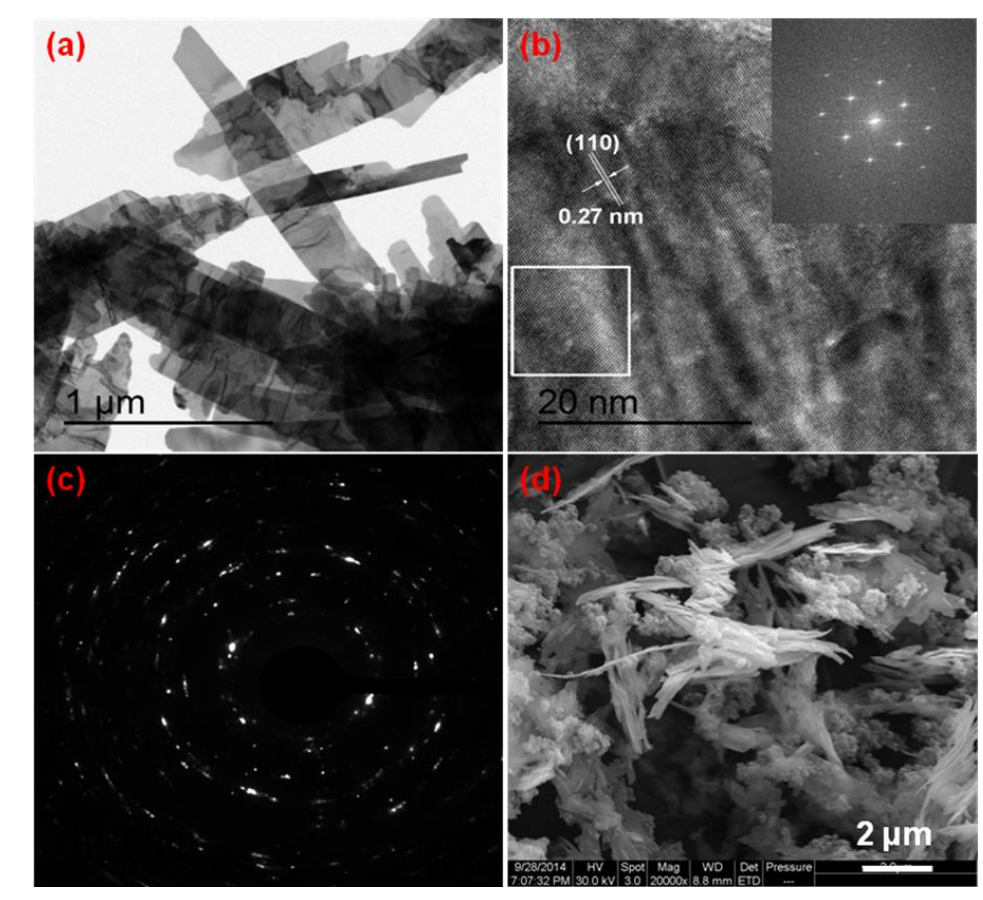

Figure 3. (a) Transmission electron microscopy (TEM) image of bamboo leaf-like $\mathrm{CuO}(\mathrm{b})$; (b) Highresolution transmission electron microscope (HRTEM) image of bamboo leaf-like $\mathrm{CuO}(\mathrm{b})$ and the corresponding fast Fourier transform(FFT) pattern (insert); (c) Selected area electron diffraction (SAED) pattern of bamboo leaf-like $\mathrm{CuO}(\mathrm{b})$; and, (d) SEM image of $\mathrm{Al} / \mathrm{CuO}(\mathrm{b})$ nanothermites.

The XRD was used to analyze the phase microstructure, and the results are shown in Figure 5. From the diffraction pattern, the characteristic diffraction peaks of the bamboo leaf-like $\mathrm{CuO}(\mathrm{b})$ and flaky-shaped $\mathrm{CuO}(\mathrm{f})$ observed at the $2 \theta$ values of $32.95,35.84,39.05,49.05,53.79,58.71,61.76,66.33$, $68.19,72.77$, and $75.48^{\circ}$ can be assigned as the (110), (-111), (111), (-202), (020), (202), (-311), (-113), (310), (311), and (-222) planes of CuO (JCPDS No. 65-2309). Additionally, the bamboo leaf-like CuO(b) and flaky-shaped $\mathrm{CuO}(\mathrm{f})$ are attributed to the monoclinic system, space group $\mathrm{C} 2 / \mathrm{c}(15)$ with $a=4.662 \AA$, $b=3.416 \AA, c=13.7495 \AA$, and $\alpha=\beta=\gamma=90^{\circ}$. The XRD pattern also reveals that there are no unknown crystalline phase and impurities in the bamboo leaf-like $\mathrm{CuO}(\mathrm{b})$ and flaky-shaped $\mathrm{CuO}(\mathrm{f})$ samples. After the bamboo leaf-like $\mathrm{CuO}(\mathrm{b})$ and flaky-shaped $\mathrm{CuO}(\mathrm{f})$ were mixed with $\mathrm{Al}$ nanopowders, it also presented the characteristic diffraction peaks of $\mathrm{Al}$ in the $\mathrm{Al} / \mathrm{CuO}(\mathrm{b})$ and $\mathrm{Al} / \mathrm{CuO}(\mathrm{f})$ nanothermites. The characteristic diffraction peaks correspond to the (111), (200), (220), and (311) planes of face-centered cubic structure Al (JCPDS No. 65-2869), as shown in Figure 5a,c. Additionally, there are also no other unknown crystalline phase and impurities in $\mathrm{Al} / \mathrm{CuO}(\mathrm{b})$ and $\mathrm{Al} / \mathrm{CuO}(\mathrm{f})$ nanothermites. This means that there is no chemical reaction between $\mathrm{Al}$ nanopowders and $\mathrm{CuO}$. 


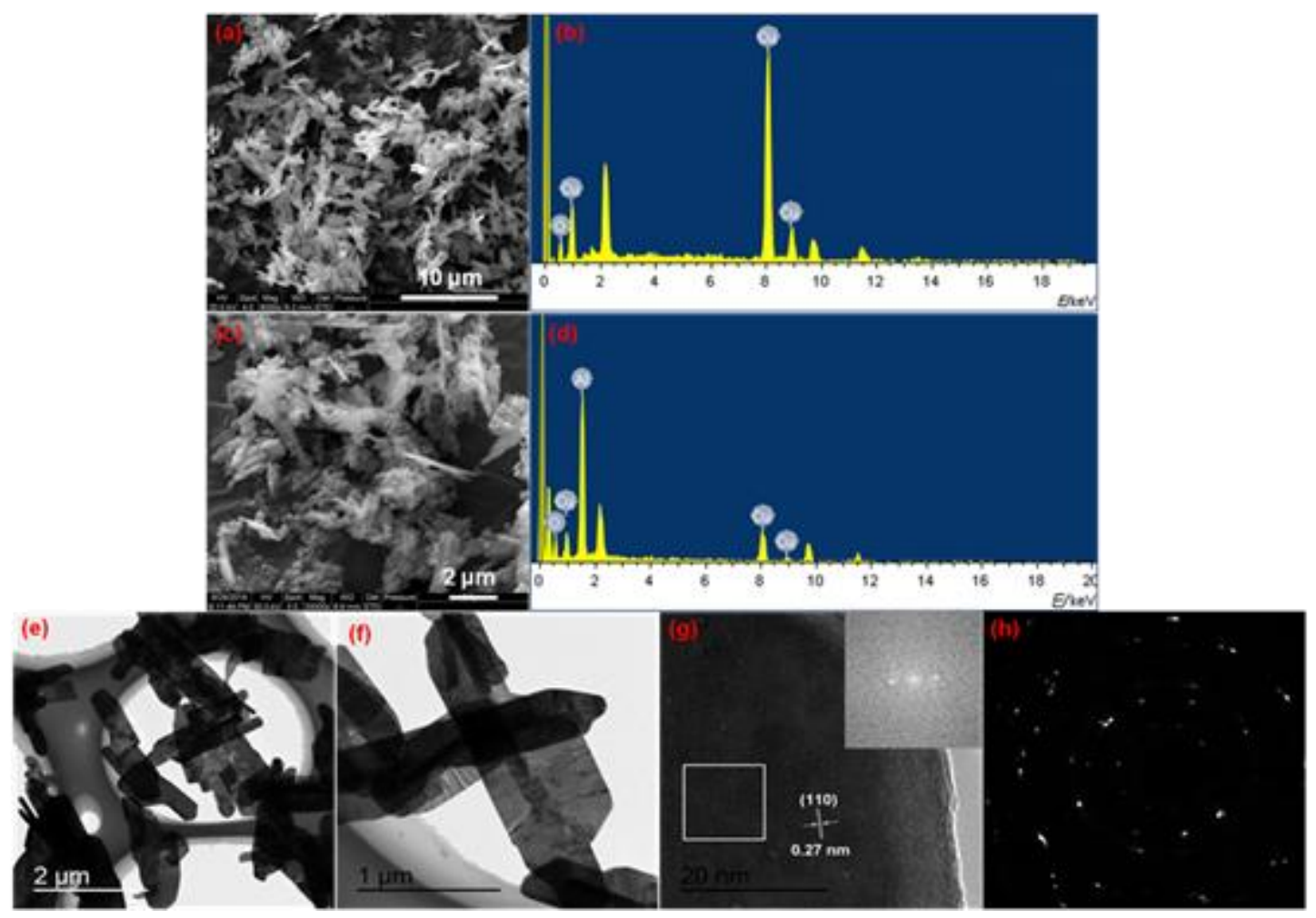

Figure 4. (a) SEM image of flaky-shaped $\mathrm{CuO}(\mathrm{f})$; (b) Energy-dispersive X-ray spectroscopy (EDS) pattern of flaky-shaped $\mathrm{CuO}(\mathrm{f})$; (c) SEM image of $\mathrm{Al} / \mathrm{CuO}(\mathrm{f})$ nanothermites; (d) EDS pattern of $\mathrm{Al} / \mathrm{CuO}(\mathrm{f})$ nanothermites; (e,f) are TEM images of flaky-shaped $\mathrm{CuO}(\mathrm{f})$; (g) HRTEM image of flaky-shaped $\mathrm{CuO}(\mathrm{f})$ and the corresponding FFT pattern (insert); and, (h) SAED pattern of flaky-shaped $\mathrm{CuO}(\mathrm{f})$.

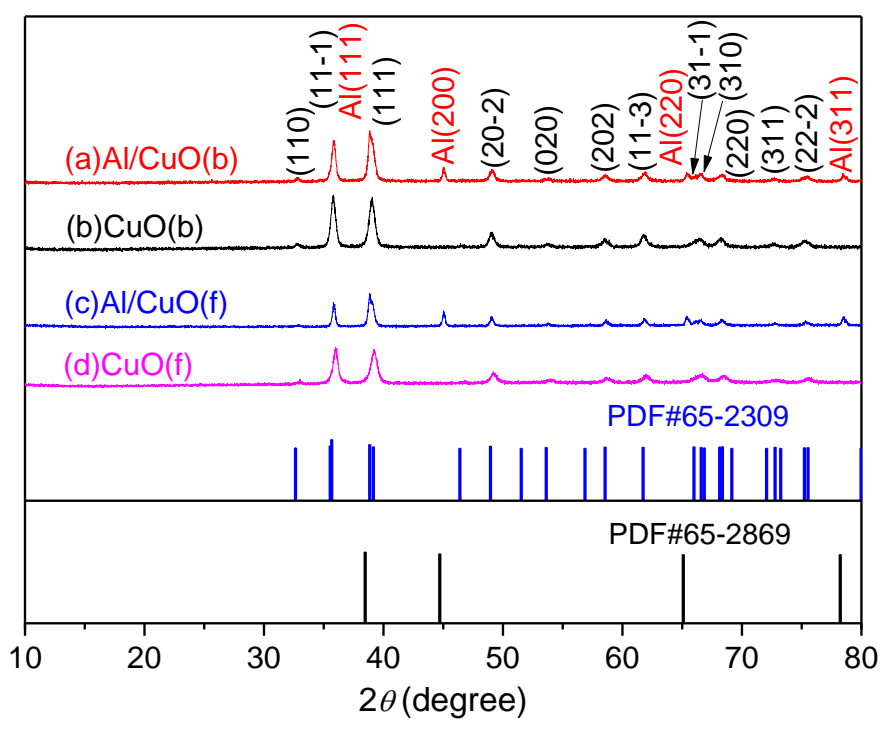

Figure 5. X-ray diffraction (XRD) patterns of different $\mathrm{CuO}$ and $\mathrm{Al} / \mathrm{CuO}$ nanothermites. (a) $\mathrm{Al} / \mathrm{CuO}(\mathrm{b})$; (b) $\mathrm{CuO}($ b); (c) $\mathrm{Al} / \mathrm{CuO}(\mathrm{f})$; and, (d) $\mathrm{CuO}$ (f).

\subsection{Effect of $\mathrm{CuO}$ and $\mathrm{Al} / \mathrm{CuO}$ on Thermal Decomposition of $\mathrm{NC}$}

The composite materials of $\mathrm{CuO}(\mathrm{b})-\mathrm{NC}, \mathrm{CuO}(\mathrm{f})-\mathrm{NC}, \mathrm{Al} / \mathrm{CuO}(\mathrm{b})-\mathrm{NC}$, and $\mathrm{Al} / \mathrm{CuO}(\mathrm{f})-\mathrm{NC}$ were prepared by mixing $\mathrm{NC}$ with $\mathrm{CuO}$ or $\mathrm{Al} / \mathrm{CuO}$ to analyze the effect of bamboo leaf-like $\mathrm{CuO}(\mathrm{b})$, flaky-shaped $\mathrm{CuO}(\mathrm{f})$ and their corresponding $\mathrm{Al} / \mathrm{CuO}(\mathrm{b}), \mathrm{Al} / \mathrm{CuO}(\mathrm{f})$ nanothermites on the thermal decomposition properties of NC. Figure 6 shows their SEM images. The $\mathrm{CuO}(\mathrm{b})-\mathrm{NC}$ composite has a 
long rod shape and a rough surface. Around the rod shape structures, there are some $\mathrm{CuO}(\mathrm{b})$ particles. As can be seen from the magnified SEM image of $\mathrm{CuO}(\mathrm{b})-\mathrm{NC}$ (Figure $6 \mathrm{~b}$ ), the surface of the NC is rough, and the bamboo leaf-shaped $\mathrm{CuO}(\mathrm{b})$ is adherent to the surface. The $\mathrm{Al} / \mathrm{CuO}(\mathrm{b})-\mathrm{NC}$ composite showed to be rod-shaped, and the bulk $\mathrm{Al} / \mathrm{CuO}(\mathrm{b})$ grains are dispersed on the region near the $\mathrm{NC}$ short fibers, as shown in Figure $6 \mathrm{c}$. It can be seen from Figure $6 \mathrm{~d}$ that the $\mathrm{Al} / \mathrm{CuO}(\mathrm{b})$ is adherent to the surface of the NC fibers, and there is some agglomeration on the spherical Al nanopowders and $\mathrm{CuO}$ fragments. The shape of $\mathrm{CuO}(\mathrm{f})-\mathrm{NC}$ composite is rod-shaped or block-shaped with different length and size, as shown in Figure 6e. The magnified image of $\mathrm{CuO}(\mathrm{f})-\mathrm{NC}$ (Figure $6 \mathrm{f}$ ) shows that the surface of the $\mathrm{NC}$ is rough and a large number of $\mathrm{CuO}$ fragments adherent on the surface. The SEM images of $\mathrm{Al} / \mathrm{CuO}(\mathrm{f})-\mathrm{NC}$ is similar to the $\mathrm{Al} / \mathrm{CuO}(\mathrm{b})-\mathrm{NC}$, and the structure is a short rod shape and the surface is rough, as shown in Figure $6 \mathrm{~g}$. There are also some agglomerations on the spherical $\mathrm{Al}$ nanopowders and $\mathrm{CuO}$ fragments (see Figure $6 \mathrm{~h}$ ).

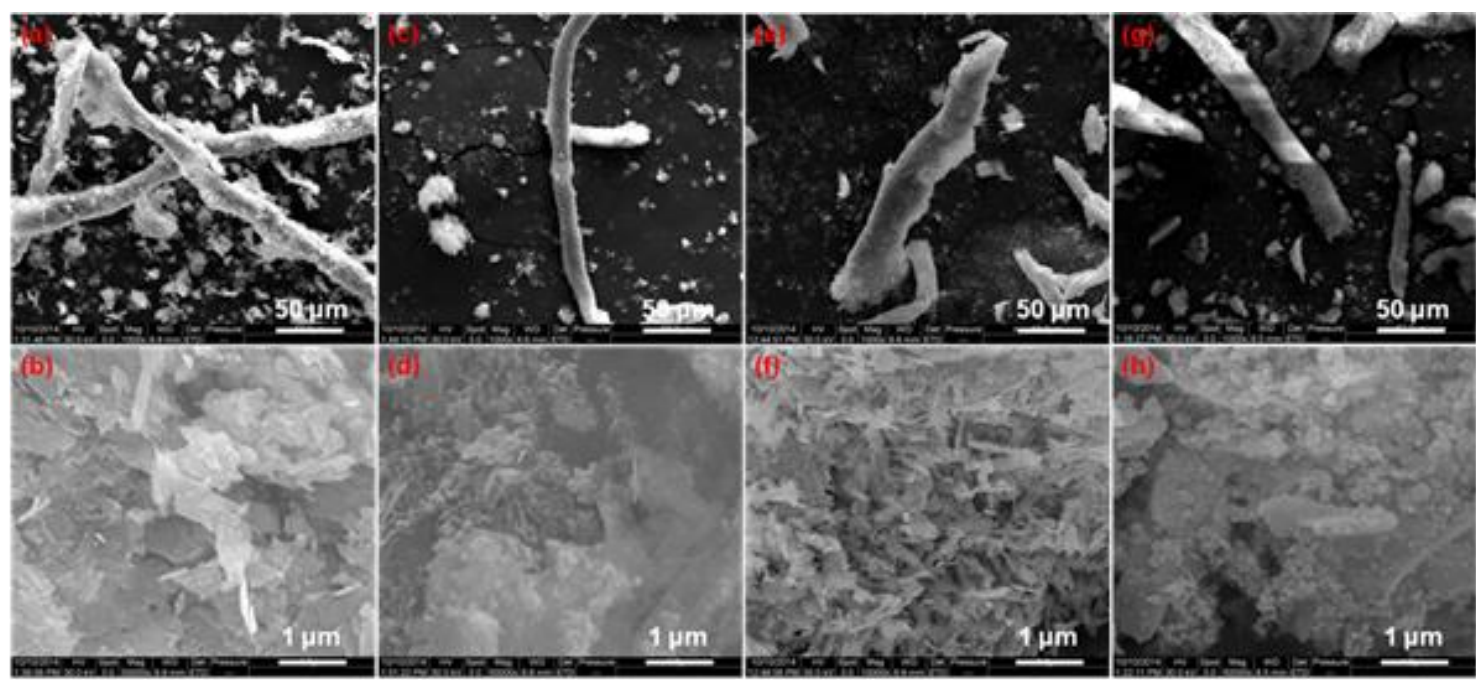

Figure 6. SEM images of different CuO-nitrocellulose (NC) and $\mathrm{Al} / \mathrm{CuO}-\mathrm{NC}$ composites. (a,b) $\mathrm{CuO}(\mathrm{b})-\mathrm{NC}$; (c,d) $\mathrm{Al} / \mathrm{CuO}(\mathrm{b})-\mathrm{NC}$; (e,f) $\mathrm{CuO}(\mathrm{f})-\mathrm{NC}$; and, (g,h) $\mathrm{Al} / \mathrm{CuO}(\mathrm{f})-\mathrm{NC}$.

\subsubsection{Compatibility Analysis}

Figure 7 is the DSC experimental result of $\mathrm{NC}, \mathrm{CuO}(\mathrm{b})-\mathrm{NC}, \mathrm{Al} / \mathrm{CuO}(\mathrm{b})-\mathrm{NC}, \mathrm{CuO}(\mathrm{f})-\mathrm{NC}$, and $\mathrm{Al} / \mathrm{CuO}(\mathrm{f})-\mathrm{NC}$ at a heating rate of $10{ }^{\circ} \mathrm{C} \cdot \mathrm{min}^{-1}$. There is only one exothermic peak in the thermal decomposition process of the five materials, and their peak temperatures are $209.7^{\circ} \mathrm{C}, 209.2^{\circ} \mathrm{C}, 209.5^{\circ} \mathrm{C}$, $209.2^{\circ} \mathrm{C}$, and $209.3^{\circ} \mathrm{C}$. When compared with the $\mathrm{NC}$, the thermal decomposition peak temperatures of $\mathrm{CuO}(\mathrm{b})-\mathrm{NC}, \mathrm{CuO}(\mathrm{f})-\mathrm{NC}, \mathrm{Al} / \mathrm{CuO}(\mathrm{b})-\mathrm{NC}$, and $\mathrm{Al} / \mathrm{CuO}(\mathrm{f})-\mathrm{NC}$ are lower than that of $\mathrm{NC}$ at $0.5^{\circ} \mathrm{C}, 0.1^{\circ} \mathrm{C}$, $0.5^{\circ} \mathrm{C}$, and $0.4^{\circ} \mathrm{C}$, respectively. These results indicate that there is no reaction at a low temperature between $\mathrm{NC}$ and other $\mathrm{Al}$ and $\mathrm{CuO}$ reactants, and the compatibility of the bamboo leaf-like $\mathrm{CuO}(\mathrm{b})$, flaky-shaped $\mathrm{CuO}(\mathrm{f}), \mathrm{Al} / \mathrm{CuO}(\mathrm{b}), \mathrm{Al} / \mathrm{CuO}(\mathrm{f})$ with $\mathrm{NC}$ is good. Therefore, the composites can be used as a component in the preparation of propellants and explosives. 


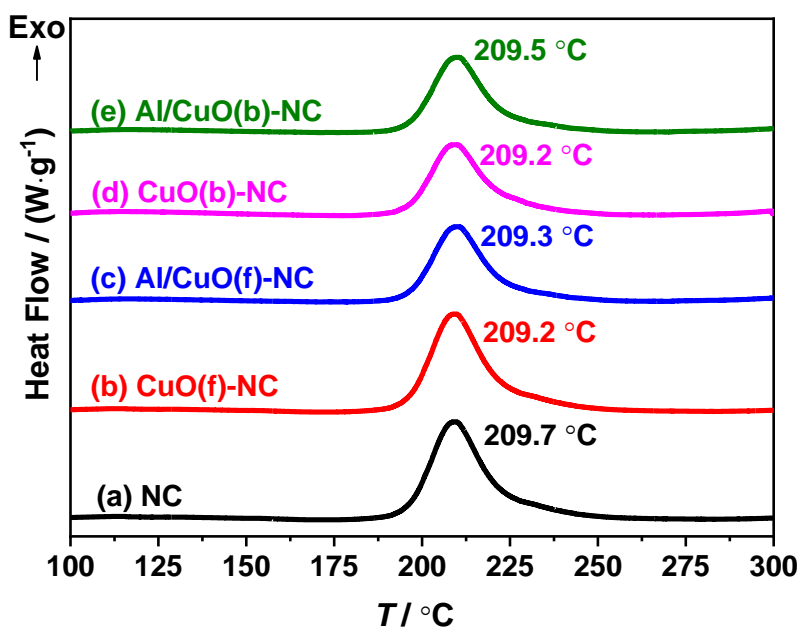

Figure 7. Differential scanning calorimetry (DSC) curves of $\mathrm{NC}, \mathrm{CuO}(\mathrm{b})-\mathrm{NC}, \mathrm{Al} / \mathrm{CuO}(\mathrm{b})-\mathrm{NC}, \mathrm{CuO}(\mathrm{f})-\mathrm{NC}$, and $\mathrm{Al} / \mathrm{CuO}(\mathrm{f})-\mathrm{NC}$ obtained at a heating rate of $10^{\circ} \mathrm{C} \cdot \mathrm{min}^{-1}$.

To obtain a better understanding of the effect of the thermite reaction between $\mathrm{Al}$ nanopowders and $\mathrm{CuO}$ to the thermal decomposition of $\mathrm{NC}$, the thermal reaction characteristics of $\mathrm{Al} / \mathrm{CuO}(\mathrm{b})$ and $\mathrm{Al} / \mathrm{CuO}(\mathrm{f})$ were investigated by DSC. Figure 8 shows the DSC curves for $\mathrm{Al} / \mathrm{CuO}(\mathrm{b})$ and $\mathrm{Al} / \mathrm{CuO}(\mathrm{f})$ nanothermites at a heating rate of $10{ }^{\circ} \mathrm{C} \cdot \mathrm{min}^{-1}$. One can see that the exothermic peak temperature of and $\mathrm{Al} / \mathrm{CuO}(\mathrm{f})$ nanothermites are almost the same, but the releasing heat per unit mass of $\mathrm{Al} / \mathrm{CuO}(\mathrm{b})$ $\left(1153 \mathrm{~J} \cdot \mathrm{g}^{1}\right)$ is obviously higher than the $\mathrm{Al} / \mathrm{CuO}(\mathrm{f})\left(681.5 \mathrm{~J} \cdot \mathrm{g}^{1}\right)$. The weak endothermic peaks were observed at about $654^{\circ} \mathrm{C}$ from the DSC curves of $\mathrm{Al} / \mathrm{CuO}(\mathrm{b})$ and $\mathrm{Al} / \mathrm{CuO}(\mathrm{f})$ nanothermites. These are the melting peak of $\mathrm{Al}$. The molten aluminum continues to react with $\mathrm{CuO}$. The releasing heat per unit mass of the $\mathrm{Al} / \mathrm{CuO}(\mathrm{b})$ after the melting of aluminum is approximately $101.0 \mathrm{~J} \cdot \mathrm{g}^{1}$, and the $\mathrm{Al} / \mathrm{CuO}(\mathrm{f})$ is very little. It can also see that the temperature of main exothermic peak for $\mathrm{Al} / \mathrm{CuO}(\mathrm{b})$ and $\mathrm{Al} / \mathrm{CuO}$ (f) nanothermites is far lower than the melting temperature of aluminum. The main exothermic peak temperatures of the thermite reaction are also much higher than the thermal decomposition of $\mathrm{CuO}-\mathrm{NC}$ and $\mathrm{Al} / \mathrm{CuO}-\mathrm{NC}$, as shown in Figure 7. This can further explain there being no reaction at low temperature between $\mathrm{NC}$ and other $\mathrm{Al}$ or $\mathrm{Al} / \mathrm{CuO}$.

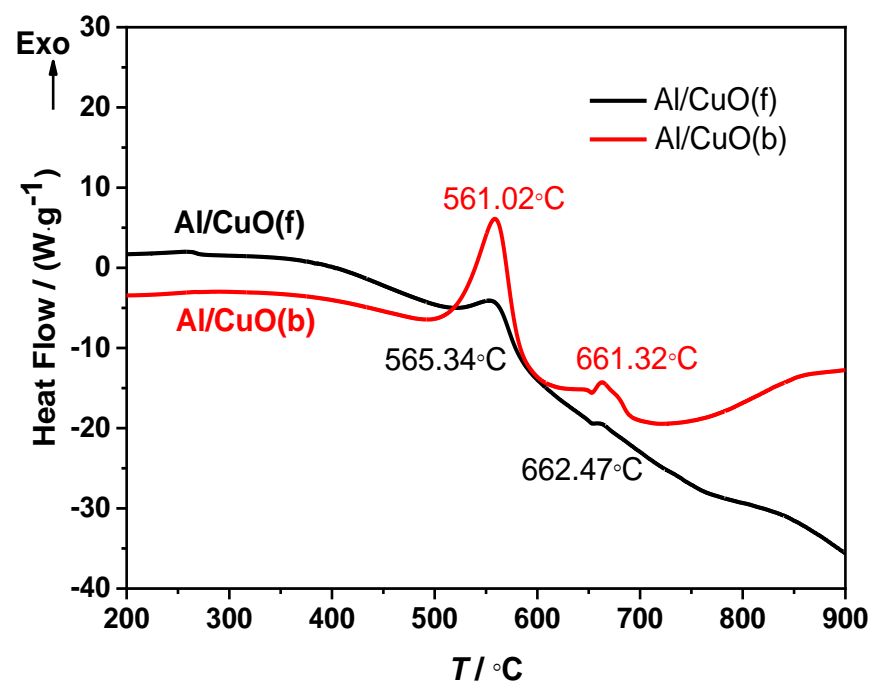

Figure 8. DSC curves of $\mathrm{Al} / \mathrm{CuO}(\mathrm{f})$ and $\mathrm{Al} / \mathrm{CuO}(\mathrm{b})$ at a heating rate of $10^{\circ} \mathrm{C} \cdot \mathrm{min}^{-1}$. 


\subsubsection{Non-isothermal Kinetic Analysis}

In order to explore the reaction mechanism of the intense exothermic decomposition process of $\mathrm{NC}, \mathrm{CuO}(\mathrm{b})-\mathrm{NC}, \mathrm{CuO}(\mathrm{f})-\mathrm{NC}, \mathrm{Al} / \mathrm{CuO}(\mathrm{b})-\mathrm{NC}$, and $\mathrm{Al} / \mathrm{CuO}(\mathrm{f})-\mathrm{NC}$, the thermal decomposition reaction kinetics was investigated by the non-isothermal DSC method. The kinetic parameters, apparent activation energy $\left(E_{\mathrm{a}}\right)$, pre-exponential factor $(A)$, and kinetic model $f(\alpha)$ were obtained. From the non-isothermal DSC curves at different heating rates 5.0, 10.0, 15.0, 20.0, 25.0, and $30.0^{\circ} \mathrm{C} \cdot \mathrm{min}^{-1}$, one can obtained the values of the extent of conversion $(\alpha)$ to corresponding temperature $(T)$ by integrating the peak area of DSC curves at different heating rates. The $E_{\alpha}$ can be obtained from the slope of the liner plot of $\lg \beta_{i}$ versus $T_{i}$ in the isoconversional Flynn-Wall-Ozawa's method (Equation (1)) [38]. Subsequently, the values of $E_{\alpha}$ to $\alpha$ can be obtained by repeating the procedure for a set of different $\alpha$.

$$
\lg \beta_{i}=\lg \left[\frac{A E_{\alpha}}{R G(\alpha)}\right]-2.315-0.4567 \frac{E_{\alpha}}{R T_{\alpha, i}} i=1,2,3,4,5,6
$$

where, $\beta$ is heating rate $\left(\mathrm{K} \cdot \mathrm{min}^{-1}\right) ; A$ is pre-exponential factor $\left(\mathrm{s}^{-1}\right) ; \alpha$ is the extent of conversion; $E_{\alpha}$ is activation energy $\left(\mathrm{J} \cdot \mathrm{mol}^{-1}\right)$ at $\alpha ; R$ is universal gas constant $\left(8.314 \mathrm{~J} \cdot \mathrm{mol}^{-1} \cdot \mathrm{K}^{-1}\right) ; G(\alpha)$ is the integral form of the reaction model; and, $T$ is temperature $(K)$. Some of the reaction models used in the non-isothermal kinetic analysis are listed in the literature [39].

The isoconversional methods (i.e. Flynn-Wall-Ozawa's method) do not need to know the reaction model, and the more accurate activation energy can also be obtained by using a set of non-isothermal curves under different heating rates [40,41]. Figure 9 shows the dependences of $E_{\alpha}$ to $\alpha$ for NC, different $\mathrm{CuO}-\mathrm{NC}$, and $\mathrm{Al} / \mathrm{CuO}-\mathrm{NC}$. The isoconversional results of $E_{\alpha}$ to $\alpha$ are important in detecting and treating the multistep kinetics. The $E_{\alpha}-\alpha$ curves of the decomposition process for the five samples have almost the same characteristic, as can be seen from Figure 9. The activation energies of NC, different $\mathrm{CuO}-\mathrm{NC}$, and $\mathrm{Al} / \mathrm{CuO}-\mathrm{NC}$ have little changes in the range of $0.100 \sim 0.750$. Additionally, the ranges can be selected to calculate the non-isothermal reaction kinetics parameters.

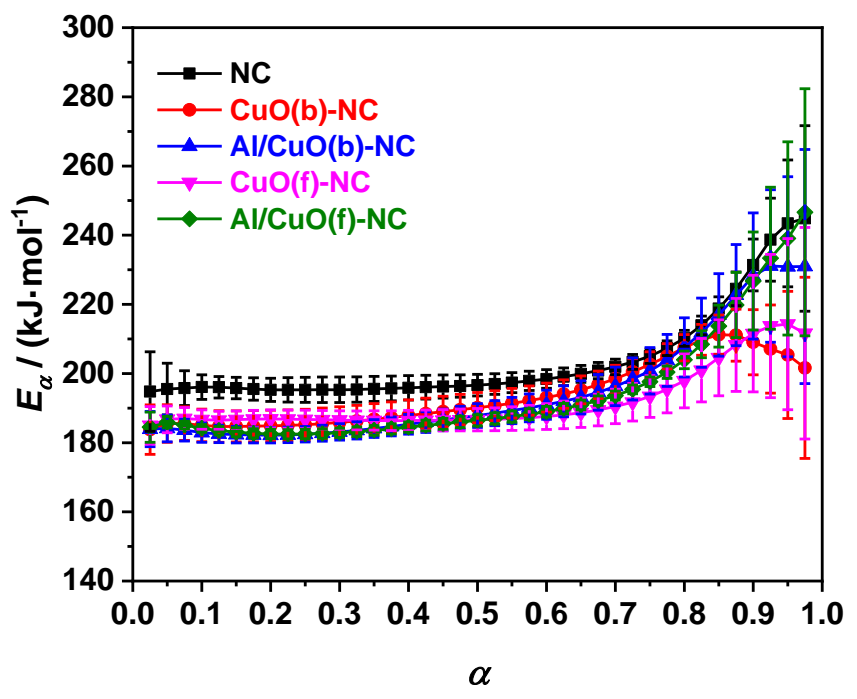

Figure 9. $E_{\alpha}$ vs $\alpha$ curves of $\mathrm{NC}, \mathrm{CuO}(\mathrm{b})-\mathrm{NC}, \mathrm{Al} / \mathrm{CuO}(\mathrm{b})-\mathrm{NC}, \mathrm{CuO}(\mathrm{f})-\mathrm{NC}$, and $\mathrm{Al} / \mathrm{CuO}(\mathrm{f})-\mathrm{NC}$ by the isoconversional Flynn-Wall-Ozawa's method.

In order to obtain the kinetic parameters, six integral methods (MacCallum-Tanner (Equation (2)), Šatava-Šesták (Equation (3)), Agrawal (Equation (4)), General integral (Equation (5)), Universal integral (Equation (6)), Ozawa (Equation (7)) and one differential method (Kissinger (Equation (8))) were employed. By substituting the $\alpha$-T data and forty-one types of kinetic model functions into the integral and differential equations, the apparent activation energy $\left(E_{\mathrm{a}}\right)$, pre-exponential factor $(A)$, 
and the most probable kinetic model $f(\alpha)$ were obtained by the logical choice method with the best linear correlation coefficient $(r)$ [27]. Generally, the normal range of $E_{\mathrm{a}}$ and $\lg \left(A / \mathrm{s}^{-1}\right)$ for energetic materials is approximately 80 to $250 \mathrm{~kJ} \cdot \mathrm{mol}^{-1}$ and 7 to 30 , respectively. The values of $E_{\mathrm{a}}, \lg \left(A / \mathrm{s}^{-1}\right)$, and corresponding linear correlation coefficient $(r)$ that was obtained by different methods at different heating rates are listed in Tables 1 and 2. The values of $E_{\mathrm{a}}$ and $\lg \left(A / \mathrm{s}^{-1}\right)$ obtained from each single non-isothermal DSC curve is in good agreement with the calculated values that were obtained by Kissinger's method and Ozawa's method. Therefore, one can conclude that the reaction mechanism of the intense exothermic decomposition process of $\mathrm{NC}, \mathrm{CuO}(\mathrm{b})-\mathrm{NC}, \mathrm{CuO}(\mathrm{f})-\mathrm{NC}, \mathrm{Al} / \mathrm{CuO}(\mathrm{b})-\mathrm{NC}$, and $\mathrm{Al} / \mathrm{CuO}(\mathrm{f})-\mathrm{NC}$ is classified as Avrami-Erofeev equation: $f(\alpha)=3 / 2(1-\alpha)[-\ln (1-\alpha)]^{1 / 3}$ (differential form) and $G(\alpha)=[-\ln (1-\alpha)]^{2 / 3}$ (integral form).

$$
\begin{gathered}
\lg G(\alpha)=\lg \left(\frac{A E_{\mathrm{a}}}{\beta R}\right)-0.4828 E_{\mathrm{a}}^{0.4357}-\frac{0.449+0.217 E_{\mathrm{a}}}{T} \frac{1}{T} \\
\lg G(\alpha)=\lg \left(\frac{A E_{\mathrm{a}}}{\beta R}\right)-2.315-0.4567 \frac{E_{\mathrm{a}}}{R T} \\
\ln \left[\frac{G(\alpha)}{T^{2}}\right]=\ln \left[\frac{A R}{\beta E_{\mathrm{a}}} \frac{1-2\left(\frac{R T}{E_{\mathrm{a}}}\right)}{1-5\left(\frac{R T}{E_{\mathrm{a}}}\right)^{2}}\right]-\frac{E_{\mathrm{a}}}{R T} \\
\ln \left[\frac{G(\alpha)}{T^{2}}\right]=\ln \left[\frac{A R}{\beta E_{\mathrm{a}}}\left(1-\frac{2 R T}{E_{\mathrm{a}}}\right)\right]-\frac{E_{\mathrm{a}}}{R T} \\
\ln \left[\frac{G(\alpha)}{T-T_{0}}\right]=\ln \left(\frac{A}{\beta}\right)-\frac{E_{\mathrm{a}}}{R T} \\
\lg \left[\frac{A E_{\mathrm{eO}(\text { or pO})}}{R G(\alpha)}\right]-2.315-0.4567 \frac{E_{\mathrm{OO}}(\text { or pO) }}{R T_{\mathrm{e}}(\text { or } \mathrm{p})} \\
\ln \left(\frac{\beta}{T_{\mathrm{p}}^{2}}\right)=\ln \left(\frac{A R}{E_{\mathrm{K}}}\right)-\frac{E_{\mathrm{K}}}{R T_{\mathrm{p}}}
\end{gathered}
$$

where, $\beta$ is heating rate $\left(\mathrm{K} \cdot \mathrm{min}^{1}\right) ; A$ is pre-exponential factor $\left(\mathrm{s}^{-1}\right) ; E_{\mathrm{a}}$ is apparent activation energy $\left(\mathrm{J} \cdot \mathrm{mol}^{-1}\right) ; R$ is universal gas constant $\left(8.314 \mathrm{~J} \cdot \mathrm{mol}^{-1} \cdot \mathrm{K}^{-1}\right) ; G(\alpha)$ is the integral form of the reaction model; $\alpha$ is the extent of conversion; $T$ is temperature $(\mathrm{K}) ; T_{0}$ is the initial temperature (K) at which DSC curve deviates from the baseline of the non-isothermal DSC curve; $T_{\mathrm{e}}$ is the onset temperature $(\mathrm{K})$; $T_{\mathrm{p}}$ is the peak temperature $(\mathrm{K}) ; E_{\mathrm{eO}}\left(\mathrm{J} \cdot \mathrm{mol}^{-1}\right)$; and, $E_{\mathrm{pO}}\left(\mathrm{J} \cdot \mathrm{mol}^{-1}\right)$ are the apparent activation energy obtained from $T_{\mathrm{e}}$ and $T_{\mathrm{p}}$ by Ozawa's method, respectively; $E_{\mathrm{K}}$ is the apparent activation energy $\left(\mathrm{J} \cdot \mathrm{mol}^{-1}\right)$ obtained from $T_{\mathrm{p}}$ by Kissinger's method. 
Table 1. Calculated values of kinetic parameters of decomposition reaction for $\mathrm{NC}$, bamboo leaf-like $\mathrm{CuO}(\mathrm{b})-\mathrm{NC}$, and $\mathrm{Al} / \mathrm{CuO}(\mathrm{b})-\mathrm{NC}$.

\begin{tabular}{|c|c|c|c|c|c|c|c|c|c|c|}
\hline \multirow{2}{*}{ Method } & \multirow{2}{*}{$\beta /\left({ }^{\circ} \mathrm{C} \cdot \min ^{-1}\right)$} & \multicolumn{3}{|c|}{ NC } & \multicolumn{3}{|c|}{$\mathrm{CuO}(\mathrm{b})-\mathrm{NC}$} & \multicolumn{3}{|c|}{$\mathrm{Al} / \mathrm{CuO}(\mathrm{b})-\mathrm{NC}$} \\
\hline & & $E_{\mathrm{a}} /\left(\mathrm{kJ} \cdot \mathrm{mol}^{-1}\right)$ & $\lg \left(A / \mathrm{s}^{-1}\right)$ & $r$ & $E_{\mathrm{a}} /\left(\mathrm{kJ} \cdot \mathrm{mol}^{-1}\right)$ & $\lg \left(A / \mathrm{s}^{-1}\right)$ & $r$ & $E_{\mathrm{a}} /\left(\mathrm{kJ} \cdot \mathrm{mol}^{-1}\right)$ & $\lg \left(A / \mathrm{s}^{-1}\right)$ & $r$ \\
\hline \multirow{6}{*}{ MacCallum-Tanner } & 5.0 & $208.0 \pm 3.5$ & $20.6 \pm 0.4$ & 0.9983 & $180.3 \pm 5.3$ & $17.5 \pm 0.5$ & 0.9927 & $176.2 \pm 5.1$ & $17.1 \pm 0.4$ & 0.9917 \\
\hline & 10.0 & $205.4 \pm 4.2$ & $20.3 \pm 0.4$ & 0.9984 & $183.3 \pm 5.8$ & $17.9 \pm 0.2$ & 0.9935 & $184.3 \pm 4.7$ & $18.0 \pm 0.3$ & 0.9920 \\
\hline & 15.0 & $209.3 \pm 3.4$ & $20.7 \pm 0.4$ & 0.9988 & $187.3 \pm 5.7$ & $18.3 \pm 0.4$ & 0.9930 & $184.2 \pm 5.8$ & $18.0 \pm 0.4$ & 0.9925 \\
\hline & 20.0 & $209.3 \pm 2.7$ & $20.7 \pm 0.6$ & 0.9987 & $182.6 \pm 4.8$ & $17.8 \pm 0.6$ & 0.9958 & $184.6 \pm 5.7$ & $18.0 \pm 0.2$ & 0.9927 \\
\hline & 25.0 & $211.8 \pm 5.1$ & $20.9 \pm 0.4$ & 0.9990 & $192.6 \pm 4.8$ & $18.9 \pm 0.4$ & 0.9934 & $181.7 \pm 4.4$ & $17.7 \pm 0.4$ & 0.9943 \\
\hline & 30.0 & $210.1 \pm 4.5$ & $20.8 \pm 0.4$ & 0.9982 & $187.7 \pm 4.1$ & $18.4 \pm 0.3$ & 0.9962 & $182.3 \pm 4.3$ & $17.8 \pm 0.3$ & 0.9959 \\
\hline \multirow{6}{*}{ Šatava-Šesták } & 5.0 & $204.6 \pm 3.9$ & $20.2 \pm 0.4$ & 0.9983 & $178.4 \pm 3.2$ & $17.3 \pm 0.6$ & 0.9927 & $174.6 \pm 3.7$ & $16.9 \pm 0.4$ & 0.9917 \\
\hline & 10.0 & $202.1 \pm 5.2$ & $19.9 \pm 0.6$ & 0.9984 & $181.2 \pm 4.0$ & $17.7 \pm 0.5$ & 0.9935 & $182.2 \pm 6.0$ & $17.8 \pm 0.3$ & 0.9920 \\
\hline & 15.0 & $205.8 \pm 5.4$ & $20.4 \pm 0.3$ & 0.9988 & $185.0 \pm 5.1$ & $18.1 \pm 0.3$ & 0.9930 & $182.1 \pm 6.7$ & $17.8 \pm 0.2$ & 0.9925 \\
\hline & 20.0 & $205.8 \pm 4.2$ & $20.3 \pm 0.3$ & 0.9987 & $180.6 \pm 4.7$ & $17.6 \pm 0.5$ & 0.9958 & $182.5 \pm 6.3$ & $17.8 \pm 0.4$ & 0.9927 \\
\hline & 25.0 & $208.1 \pm 3.6$ & $20.6 \pm 0.5$ & 0.9990 & $190.0 \pm 5.6$ & $18.7 \pm 0.3$ & 0.9934 & $179.8 \pm 5.3$ & $17.5 \pm 0.2$ & 0.9943 \\
\hline & 30.0 & $206.6 \pm 5.6$ & $20.4 \pm 0.4$ & 0.9982 & $185.4 \pm 5.0$ & $18.1 \pm 0.3$ & 0.9962 & $180.3 \pm 4.9$ & $17.6 \pm 0.3$ & 0.9959 \\
\hline \multirow{6}{*}{ Agrawal } & 5.0 & $207.2 \pm 5.6$ & $20.5 \pm 0.5$ & 0.9982 & $179.7 \pm 4.0$ & $17.5 \pm 0.3$ & 0.9920 & $175.7 \pm 4.5$ & $17.1 \pm 0.3$ & 0.9909 \\
\hline & 10.0 & $204.5 \pm 5.3$ & $20.2 \pm 0.6$ & 0.9983 & $182.6 \pm 4.8$ & $17.8 \pm 0.5$ & 0.9929 & $183.6 \pm 4.0$ & $17.9 \pm 0.3$ & 0.9913 \\
\hline & 15.0 & $208.4 \pm 4.8$ & $20.6 \pm 0.4$ & 0.9987 & $186.5 \pm 5.8$ & $18.3 \pm 0.5$ & 0.9924 & $183.4 \pm 3.4$ & $17.9 \pm 0.2$ & 0.9919 \\
\hline & 20.0 & $208.3 \pm 4.0$ & $20.6 \pm 0.6$ & 0.9986 & $181.9 \pm 3.5$ & $17.8 \pm 0.3$ & 0.9954 & $183.8 \pm 4.6$ & $18.0 \pm 0.3$ & 0.9920 \\
\hline & 25.0 & $210.7 \pm 5.2$ & $20.8 \pm 0.6$ & 0.9990 & $191.7 \pm 4.4$ & $18.8 \pm 0.5$ & 0.9928 & $180.9 \pm 3.6$ & $17.6 \pm 0.2$ & 0.9938 \\
\hline & 30.0 & $209.0 \pm 4.7$ & $20.7 \pm 0.6$ & 0.9981 & $186.8 \pm 6.7$ & $18.3 \pm 0.5$ & 0.9958 & $181.5 \pm 4.8$ & $17.7 \pm 0.4$ & 0.9955 \\
\hline \multirow{6}{*}{ General integral } & 5.0 & $205.8 \pm 6.2$ & $19.0 \pm 0.4$ & 0.9985 & $178.3 \pm 6.7$ & $16.0 \pm 0.6$ & 0.9919 & $174.3 \pm 5.3$ & $15.6 \pm 0.2$ & 0.9908 \\
\hline & 10.0 & $203.3 \pm 6.08$ & $18.7 \pm 0.3$ & 0.9983 & $181.3 \pm 6.9$ & $16.4 \pm 0.3$ & 0.9928 & $182.3 \pm 5.9$ & $16.5 \pm 0.3$ & 0.9912 \\
\hline & 15.0 & $207.2 \pm 4.9$ & $19.1 \pm 0.5$ & 0.9987 & $185.3 \pm 6.8$ & $16.8 \pm 0.5$ & 0.9923 & $182.2 \pm 6.1$ & $16.5 \pm 0.3$ & 0.9918 \\
\hline & 20.0 & $207.2 \pm 5.3$ & $19.1 \pm 0.4$ & 0.9986 & $180.7 \pm 3.8$ & $16.3 \pm 0.5$ & 0.9954 & $182.7 \pm 5.7$ & $16.5 \pm 0.4$ & 0.9920 \\
\hline & 25.0 & $209.6 \pm 6.2$ & $19.3 \pm 0.6$ & 0.9989 & $190.6 \pm 4.4$ & $17.4 \pm 0.3$ & 0.9928 & $179.8 \pm 4.3$ & $16.2 \pm 0.3$ & 0.9937 \\
\hline & 30.0 & $208.0 \pm 4.7$ & $19.2 \pm 0.5$ & 0.9981 & $185.8 \pm 3.5$ & $16.9 \pm 0.4$ & 0.9958 & $180.4 \pm 5.9$ & $16.3 \pm 0.4$ & 0.9955 \\
\hline \multirow{6}{*}{ Universal integral } & 5.0 & $207.2 \pm 4.3$ & $20.5 \pm 0.6$ & 0.9982 & $179.7 \pm 6.9$ & $17.5 \pm 0.4$ & 0.9920 & $175.7 \pm 3.9$ & $17.1 \pm 0.2$ & 0.9909 \\
\hline & 10.0 & $204.5 \pm 5.3$ & $20.2 \pm 0.3$ & 0.9983 & $182.6 \pm 6.5$ & $17.8 \pm 0.5$ & 0.9929 & $183.6 \pm 4.8$ & $17.9 \pm 0.2$ & 0.9913 \\
\hline & 15.0 & $208.4 \pm 4.6$ & $20.6 \pm 0.5$ & 0.9987 & $186.5 \pm 5.1$ & $18.3 \pm 0.3$ & 0.9924 & $183.4 \pm 5.7$ & $17.9 \pm 0.4$ & 0.9919 \\
\hline & 20.0 & $208.3 \pm 3.9$ & $20.6 \pm 0.4$ & 0.9986 & $181.9 \pm 6.1$ & $17.8 \pm 0.3$ & 0.9954 & $183.8 \pm 3.5$ & $18.0 \pm 0.4$ & 0.9920 \\
\hline & 25.0 & $210.7 \pm 5.4$ & $20.8 \pm 0.6$ & 0.9990 & $191.7 \pm 6.1$ & $18.8 \pm 0.4$ & 0.9928 & $180.9 \pm 5.5$ & $17.7 \pm 0.2$ & 0.9938 \\
\hline & 30.0 & $209.0 \pm 6.1$ & $20.7 \pm 0.4$ & 0.9981 & $186.8 \pm 5.6$ & $18.3 \pm 0.5$ & 0.9958 & $181.5 \pm 4.4$ & $17.7 \pm 0.4$ & 0.9955 \\
\hline Mean & & $207.5 \pm 4.8$ & $20.2 \pm 0.5$ & & $184.5 \pm 5.2$ & $17.8 \pm 0.4$ & & $181.1 \pm 5.0$ & $17.4 \pm 0.3$ & \\
\hline \multirow{2}{*}{ Flynn-Wall-Ozawa } & & $185.7 \pm 1.9\left(E_{\mathrm{eO}}\right)$ & & 0.9998 & $178.7 \pm 3.6\left(E_{\mathrm{eO}}\right)$ & & 0.9919 & $176.3 \pm 5.3\left(E_{\mathrm{eO}}\right)$ & & 0.9982 \\
\hline & & $197.6 \pm 6.4\left(E_{\mathrm{pO}}\right)$ & & 0.9979 & $187.0 \pm 4.8\left(E_{\mathrm{pO}}\right)$ & & 0.9987 & $183.6 \pm 2.6\left(E_{\mathrm{pO}}\right)$ & & 0.9996 \\
\hline Kissinger & & $199.7 \pm 6.8\left(E_{\mathrm{K}}\right)$ & $19.8 \pm 0.7$ & 0.9977 & $188.6 \pm 5.0\left(E_{\mathrm{K}}\right)$ & $18.6 \pm 0.6$ & 0.9986 & $185.0 \pm 2.7\left(E_{\mathrm{K}}\right)$ & $18.2 \pm 0.3$ & 0.9996 \\
\hline $\operatorname{Mean}\left(E_{\mathrm{eO}}, E_{\mathrm{pO}}, E_{\mathrm{K}}\right)$ & & $194.3 \pm 5.0$ & & & $184.8 \pm 4.5$ & & & $181.6 \pm 3.5$ & & \\
\hline
\end{tabular}


Table 2. Calculated values of kinetic parameters of decomposition reaction for flaky-shaped $\mathrm{CuO}(\mathrm{f})-\mathrm{NC}$ and $\mathrm{Al} / \mathrm{CuO}(\mathrm{f})-\mathrm{NC}$.

\begin{tabular}{|c|c|c|c|c|c|c|c|}
\hline \multirow{2}{*}{ Method } & \multirow{2}{*}{$\beta /\left({ }^{\circ} \mathrm{C} \cdot \min ^{-1}\right)$} & \multicolumn{3}{|c|}{$\mathrm{CuO}(\mathrm{f})-\mathrm{NC}$} & \multicolumn{3}{|c|}{$\mathrm{Al} / \mathrm{CuO}(\mathrm{f})-\mathrm{NC}$} \\
\hline & & $E_{\mathrm{a}} /\left(\mathrm{kJ} \cdot \mathrm{mol}^{-1}\right)$ & $\lg \left(A / s^{-1}\right)$ & $r$ & $E_{\mathrm{a}} /\left(\mathrm{kJ} \cdot \mathrm{mol}^{-1}\right)$ & $\lg \left(A / \mathrm{s}^{-1}\right)$ & $r$ \\
\hline \multirow{6}{*}{$\begin{array}{l}\text { MacCallum- } \\
\text { Tanner }\end{array}$} & 5.0 & $190.4 \pm 6.6$ & $18.6 \pm 0.4$ & 0.9917 & $177.6 \pm 5.7$ & $17.2 \pm 0.6$ & 0.9889 \\
\hline & 10.0 & $197.2 \pm 4.0$ & $19.3 \pm 0.4$ & 0.9921 & $177.7 \pm 3.5$ & $17.2 \pm 0.6$ & 0.9920 \\
\hline & 15.0 & $192.0 \pm 5.8$ & $18.8 \pm 0.5$ & 0.9928 & $176.3 \pm 4.7$ & $17.1 \pm 0.5$ & 0.9936 \\
\hline & 20.0 & $202.3 \pm 6.8$ & $19.9 \pm 0.6$ & 0.9932 & $187.8 \pm 4.9$ & $18.4 \pm 0.4$ & 0.9952 \\
\hline & 25.0 & $189.1 \pm 6.1$ & $18.4 \pm 0.5$ & 0.9925 & $179.9 \pm 3.9$ & $17.5 \pm 0.4$ & 0.9930 \\
\hline & 30.0 & $198.0 \pm 3.7$ & $19.4 \pm 0.6$ & 0.9941 & $190.6 \pm 5.5$ & $18.7 \pm 0.4$ & 0.9942 \\
\hline \multirow{6}{*}{$\begin{array}{l}\text { Šatava- } \\
\text { Šesták }\end{array}$} & 5.0 & $187.9 \pm 6.7$ & $18.4 \pm 0.5$ & 0.9917 & $175.9 \pm 3.3$ & $17.1 \pm 0.5$ & 0.9889 \\
\hline & 10.0 & $194.4 \pm 5.7$ & $19.1 \pm 0.4$ & 0.9921 & $176.0 \pm 4.5$ & $17.1 \pm 0.2$ & 0.9920 \\
\hline & 15.0 & $189.5 \pm 5.3$ & $18.5 \pm 0.5$ & 0.9928 & $174.7 \pm 3.3$ & $17.0 \pm 0.4$ & 0.9936 \\
\hline & 20.0 & $199.2 \pm 4.1$ & $19.6 \pm 0.5$ & 0.9932 & $185.5 \pm 6.1$ & $18.2 \pm 0.5$ & 0.9952 \\
\hline & 25.0 & $186.7 \pm 6.7$ & $18.2 \pm 0.5$ & 0.9925 & $178.0 \pm 6.1$ & $17.3 \pm 0.5$ & 0.9930 \\
\hline & 30.0 & $195.1 \pm 5.1$ & $19.1 \pm 0.5$ & 0.9941 & $188.1 \pm 3.8$ & $18.4 \pm 0.3$ & 0.9942 \\
\hline \multirow{6}{*}{ Agrawal } & 5.0 & $189.7 \pm 4.7$ & $18.6 \pm 0.5$ & 0.9910 & $177.1 \pm 6.6$ & $17.2 \pm 0.3$ & 0.9879 \\
\hline & 10.0 & $196.4 \pm 3.7$ & $19.3 \pm 0.6$ & 0.9915 & $177.1 \pm 5.4$ & $17.2 \pm 0.5$ & 0.9913 \\
\hline & 15.0 & $191.2 \pm 6.4$ & $18.7 \pm 0.5$ & 0.9921 & $175.6 \pm 5.3$ & $17.1 \pm 0.3$ & 0.9929 \\
\hline & 20.0 & $201.3 \pm 5.5$ & $19.8 \pm 0.5$ & 0.9926 & $187.0 \pm 3.8$ & $18.3 \pm 0.3$ & 0.9947 \\
\hline & 25.0 & $188.2 \pm 5.1$ & $18.4 \pm 0.5$ & 0.9918 & $179.1 \pm 3.7$ & $17.4 \pm 0.5$ & 0.9923 \\
\hline & 30.0 & $196.9 \pm 3.2$ & $19.3 \pm 0.4$ & 0.9936 & $189.7 \pm 3.5$ & $18.6 \pm 0.3$ & 0.9937 \\
\hline \multirow{6}{*}{$\begin{array}{l}\text { General } \\
\text { integral }\end{array}$} & 5.0 & $188.4 \pm 5.3$ & $17.1 \pm 0.5$ & 0.9909 & $175.6 \pm 4.6$ & $15.7 \pm 0.3$ & 0.9878 \\
\hline & 10.0 & $195.1 \pm 4.7$ & $17.8 \pm 0.6$ & 0.9914 & $175.8 \pm 4.2$ & $15.8 \pm 0.3$ & 0.9912 \\
\hline & 15.0 & $190.1 \pm 6.1$ & $17.3 \pm 0.5$ & 0.9921 & $174.4 \pm 5.3$ & $15.6 \pm 0.4$ & 0.9929 \\
\hline & 20.0 & $200.3 \pm 6.5$ & $18.4 \pm 0.5$ & 0.9925 & $185.9 \pm 5.8$ & $16.9 \pm 0.5$ & 0.9947 \\
\hline & 25.0 & $187.2 \pm 3.8$ & $16.9 \pm 0.4$ & 0.9918 & $178.0 \pm 5.0$ & $16.0 \pm 0.6$ & 0.9922 \\
\hline & 30.0 & $196.0 \pm 5.5$ & $17.9 \pm 0.6$ & 0.9936 & $188.6 \pm 3.2$ & $17.2 \pm 0.4$ & 0.9936 \\
\hline \multirow{6}{*}{$\begin{array}{l}\text { Universal } \\
\text { integral }\end{array}$} & 5.0 & $201.3 \pm 4.1$ & $19.8 \pm 0.6$ & 0.9926 & $177.1 \pm 5.5$ & $17.2 \pm 0.4$ & 0.9879 \\
\hline & 10.0 & $196.4 \pm 3.4$ & $19.3 \pm 0.4$ & 0.9915 & $177.1 \pm 5.0$ & $17.2 \pm 0.4$ & 0.9913 \\
\hline & 15.0 & $190.1 \pm 4.0$ & $17.3 \pm 0.4$ & 0.9921 & $175.6 \pm 6.5$ & $17.1 \pm 0.4$ & 0.9929 \\
\hline & 20.0 & $191.2 \pm 6.3$ & $18.7 \pm 0.5$ & 0.9921 & $187.0 \pm 6.8$ & $18.3 \pm 0.3$ & 0.9947 \\
\hline & 25.0 & $188.2 \pm 3.5$ & $18.4 \pm 0.6$ & 0.9918 & $179.1 \pm 6.7$ & $17.4 \pm 0.3$ & 0.9923 \\
\hline & 30.0 & $196.9 \pm 4.1$ & $19.3 \pm 0.5$ & 0.9936 & $189.7 \pm 3.4$ & $18.6 \pm 0.3$ & 0.9937 \\
\hline Mean & & $193.5 \pm 5.1$ & $18.7 \pm 0.5$ & & $180.6 \pm 4.9$ & $17.3 \pm 0.4$ & \\
\hline \multirow{2}{*}{\multicolumn{2}{|c|}{ Flynn-Wall-Ozawa }} & $177.8 \pm 5.1\left(E_{\mathrm{eO}}\right)$ & & 0.9983 & $171.5 \pm 6.8\left(E_{\mathrm{eO}}\right)$ & & 0.9968 \\
\hline & & $183.7 \pm 8.3\left(E_{\mathrm{pO}}\right)$ & & 0.9959 & $185.9 \pm 3.9\left(E_{\mathrm{pO}}\right)$ & & 0.9991 \\
\hline \multirow{2}{*}{$\begin{array}{c}\text { Kissinger } \\
\mathrm{Mean}\left(E_{\mathrm{eO}}\right. \\
\left.E_{\mathrm{pO}}, E_{\mathrm{K}}\right)\end{array}$} & & $185.1 \pm 8.7\left(E_{\mathrm{K}}\right)$ & $18.2 \pm 1.0$ & 0.9956 & $187.4 \pm 4.1\left(E_{\mathrm{K}}\right)$ & $18.5 \pm 0.4$ & 0.9990 \\
\hline & & $182.2 \pm 7.4$ & & & $181.6 \pm 4.9$ & & \\
\hline
\end{tabular}

Substituting the $E_{\mathrm{a}}$ and $A$ values (listed in Tables 1 and 2) of $\mathrm{NC}, \mathrm{CuO}(\mathrm{b})-\mathrm{NC}, \mathrm{Al} / \mathrm{CuO}(\mathrm{b})-\mathrm{NC}$, $\mathrm{CuO}(\mathrm{f})-\mathrm{NC}, \mathrm{Al} / \mathrm{CuO}(\mathrm{f})-\mathrm{NC}$, and $f(\alpha)=3 / 2(1-\alpha)[-\ln (1-\alpha)]^{1 / 3}$ into Equation (9) [42]. The kinetic equations of the intense exothermic decomposition process of $\mathrm{NC}, \mathrm{CuO}(\mathrm{b})-\mathrm{NC}, \mathrm{CuO}(\mathrm{f})-\mathrm{NC}, \mathrm{Al} / \mathrm{CuO}(\mathrm{b})-\mathrm{NC}$, and $\mathrm{Al} / \mathrm{CuO}(\mathrm{f})-\mathrm{NC}$ can be described as Equations (10)-(14), respectively.

$$
\begin{gathered}
\frac{\mathrm{d} \alpha}{\mathrm{d} T}=\frac{A}{\beta} f(\alpha) \exp \left(-\frac{E}{R T}\right) \\
\frac{\mathrm{d} \alpha}{\mathrm{d} T}=\frac{10^{20.4}}{\beta}(1-\alpha)[-\ln (1-\alpha)]^{1 / 3} \exp \left(-2.5 \times 10^{4} / T\right) \\
\frac{\mathrm{d} \alpha}{\mathrm{d} T}=\frac{10^{18.0}}{\beta}(1-\alpha)[-\ln (1-\alpha)]^{1 / 3} \exp \left(-2.2 \times 10^{4} / T\right) \\
\frac{\mathrm{d} \alpha}{\mathrm{d} T}=\frac{10^{17.6}}{\beta}(1-\alpha)[-\ln (1-\alpha)]^{1 / 3} \exp \left(-2.2 \times 10^{4} / T\right)
\end{gathered}
$$




$$
\begin{aligned}
& \frac{\mathrm{d} \alpha}{\mathrm{d} T}=\frac{10^{18.9}}{\beta}(1-\alpha)[-\ln (1-\alpha)]^{1 / 3} \exp \left(-2.3 \times 10^{4} / T\right) \\
& \frac{\mathrm{d} \alpha}{\mathrm{d} T}=\frac{10^{17.5}}{\beta}(1-\alpha)[-\ln (1-\alpha)]^{1 / 3} \exp \left(-2.2 \times 10^{4} / T\right)
\end{aligned}
$$

\subsubsection{Thermal Safety Analysis}

The simple model derived earlier in the frame of Semenov's thermal explosion theory [43] was established for estimating the thermal ignition temperature $\left(T_{\mathrm{be} 0}\right)$ and the critical temperatures of thermal explosion $\left(T_{\mathrm{bp} 0}\right)$ of as-prepared NC-based complexes. All of the calculations are based on the differential scanning calorimetry (DSC) experiments and the safety parameters, such as the thermal conductivity, particle size, mechanical properties, and pressure dependence of melting point et al., are not involved $[44,45]$.

The values of $T_{\mathrm{e} 0}$ and $T_{\mathrm{p} 0}$ can be calculated in accordance with the Equation (15) in order to obtain the self-accelerating decomposition temperature $\left(T_{\mathrm{SADT}}\right)$ of as-prepared samples. Then the value of $T_{\mathrm{SADT}}$ can be obtained by the Equation (16). The values of $T_{\mathrm{e} 0}\left(T_{\mathrm{SADT}}\right)$ and $T_{\mathrm{p} 0}$ for $\mathrm{NC}, \mathrm{CuO}(\mathrm{b})-\mathrm{NC}$, $\mathrm{CuO}(\mathrm{f})-\mathrm{NC}, \mathrm{Al} / \mathrm{CuO}(\mathrm{b})-\mathrm{NC}$, and $\mathrm{Al} / \mathrm{CuO}(\mathrm{f})-\mathrm{NC}$ are listed in Table 3.

$$
T_{\mathrm{e} i(\text { or } \mathrm{p} i)}=T_{\mathrm{e} 0(\text { or } \mathrm{p} 0)}+a \beta_{i}+b \beta_{i}{ }^{2}+c \beta_{i}^{3}
$$

where $T_{\mathrm{e}}$ is the onset temperature; $T_{\mathrm{p}}$ is the peak temperature; $\beta$ is the heating rate; $T_{\mathrm{e} 0}$ and $T_{\mathrm{p} 0}$ are the onset and peak temperatures corresponding to $\beta \rightarrow 0$, respectively; and, $a, b$, and $c$ are the polynomial coefficients; $i=1,2, \cdots, 6$.

$$
T_{\mathrm{SADT}}=T_{\mathrm{e} 0}
$$

\begin{tabular}{|c|c|c|c|c|c|c|c|c|c|}
\hline Sample & $\begin{array}{c}E_{\mathrm{a} /} / \\
\left(\mathrm{kJ} \cdot \mathrm{mol}^{-1}\right)\end{array}$ & $\lg \left(A / \mathrm{s}^{-1}\right)$ & $T_{\mathrm{e} 0} /{ }^{\circ} \mathrm{C}$ & $T_{\mathrm{p} 0} /{ }^{\circ} \mathrm{C}$ & $T_{\text {be } 0} /{ }^{\circ} \mathrm{C}$ & $T_{\mathrm{bp} 0} /{ }^{\circ} \mathrm{C}$ & $\begin{array}{c}\Delta S^{\neq} / \\
\left(\mathrm{J} \cdot \mathrm{mol}^{-1} \cdot \mathrm{K}^{-1}\right)\end{array}$ & $\begin{array}{c}\Delta H^{\neq} / \\
\left(\mathrm{kJ} \cdot \mathrm{mol}^{-1}\right)\end{array}$ & $\begin{array}{c}\Delta G^{\neq} / \\
\left(\mathrm{kJ} \cdot \mathrm{mol}^{-1}\right)\end{array}$ \\
\hline $\mathrm{NC}$ & 207.5 & 20.2 & 181.8 & 197.0 & 191.4 & 206.7 & 138.4 & 199.7 & 134.6 \\
\hline $\mathrm{CuO}(\mathrm{b})-\mathrm{NC}$ & 184.5 & 17.8 & 176.4 & 189.3 & 180.2 & 193.5 & 91.7 & 188.6 & 146.2 \\
\hline $\mathrm{Al} / \mathrm{CuO}(\mathrm{b})-\mathrm{NC}$ & 181.1 & 17.4 & 169.3 & 184.4 & 178.6 & 194.3 & 84.5 & 185.0 & 146.3 \\
\hline $\mathrm{CuO}(\mathrm{f})-\mathrm{NC}$ & 193.5 & 18.7 & 178.6 & 190.0 & 189.3 & 206.3 & 109.1 & 185.0 & 133.9 \\
\hline $\mathrm{Al} / \mathrm{CuO}(\mathrm{f})-\mathrm{NC}$ & 180.6 & 17.3 & 152.9 & 191.8 & 161.3 & 201.9 & 83.2 & 187.4 & 148.7 \\
\hline
\end{tabular}

Table 3. Calculated values of kinetic parameters of decomposition reaction for $\mathrm{NC}, \mathrm{CuO}(\mathrm{b})-\mathrm{NC}$, $\mathrm{Al} / \mathrm{CuO}(\mathrm{b})-\mathrm{NC}, \mathrm{CuO}(\mathrm{f})-\mathrm{NC}$, and $\mathrm{Al} / \mathrm{CuO}(\mathrm{f})-\mathrm{NC}$.

The $T_{\mathrm{be} 0}$ can be obtained substituting the values of $E_{\mathrm{eO}}$ (listed in Tables 1 and 2) and $T_{\mathrm{e} 0}$ (see Table 3 ) into Equation (16). The $T_{\mathrm{bp} 0}$ can also be obtained by substituting $E_{\mathrm{pO}}$ (listed in Tables 1 and 2) and $T_{\mathrm{p} 0}$ (see Table 3) into the Equation (17). The values of $T_{\mathrm{be} 0}$ and $T_{\mathrm{bp} 0}$ for $\mathrm{NC}, \mathrm{CuO}(\mathrm{b})-\mathrm{NC}, \mathrm{CuO}(\mathrm{f})-\mathrm{NC}$, $\mathrm{Al} / \mathrm{CuO}(\mathrm{b})-\mathrm{NC}$, and $\mathrm{Al} / \mathrm{CuO}(\mathrm{f})-\mathrm{NC}$ are also listed in Table 3. Generally, the value of $T_{\mathrm{b}}\left(T_{\mathrm{be} 0}\right.$ or $\left.T_{\mathrm{bp} 0}\right)$ is one of the most important evaluation parameters for thermal safety, which represent the degree of difficulty of the transition from thermal decomposition to thermal explosion. The higher the value of $T_{b}$, the transition can take place easier.

$$
T_{\mathrm{be} 0 \text { or bp } 0}=\frac{E_{\mathrm{eO} \text { or } \mathrm{pO}}-\sqrt{E_{\mathrm{eO} \text { or } \mathrm{pO}}^{2}-4 E_{\mathrm{eO} \text { or } \mathrm{pO}} R T_{\mathrm{e} 0 \text { or } \mathrm{p} 0}}}{2 R}
$$

While using $T=T_{\mathrm{p} 0}, E_{\mathrm{a}}=E_{\mathrm{K}}$, and $A=A_{\mathrm{K}}$, the values of activation entropy $\left(\Delta S^{\neq}\right)$, activation enthalpy $\left(\Delta H^{\ddagger}\right)$, and activation of activation free energy $\left(\Delta G^{\neq}\right)$of the main exothermic decomposition 
reaction of the $\mathrm{NC}, \mathrm{CuO}(\mathrm{b})-\mathrm{NC}, \mathrm{CuO}(\mathrm{f})-\mathrm{NC}, \mathrm{Al} / \mathrm{CuO}(\mathrm{b})-\mathrm{NC}$, and $\mathrm{Al} / \mathrm{CuO}(\mathrm{f})-\mathrm{NC}$ are obtained by Equation (18) to Equation (20), as listed in Table 3.

$$
\begin{gathered}
A \exp \left(-\frac{E_{\mathrm{a}}}{R T}\right)=\frac{k_{\mathrm{B}} T}{h} \exp \left(-\frac{\Delta G^{\neq}}{R T}\right) \\
\Delta H^{\neq}=E_{\mathrm{a}}-R T \\
\Delta G^{\neq}=\Delta H^{\neq}-T \Delta S^{\neq}
\end{gathered}
$$

where $k_{\mathrm{B}}$ is the Boltzmann constant, $1.38066 \times 10^{-23} \mathrm{~J} \cdot \mathrm{K}^{-1} ; h$ is the Planck constant, $6.626 \times 10^{-34} \mathrm{~J} \cdot \mathrm{s}$.

According to the previous studies $[27,28,46]$, the thermal decomposition reaction of $\mathrm{NC}$ is a typical competition reaction between the $\mathrm{O}-\mathrm{NO}_{2}$ bond rupture and the decomposition of polymer skeleton products decomposition. The $\mathrm{NO}_{2}$ gas is the initial decomposition product in the first step of high-temperature pyrolysis, similar to RDX. However, the $\mathrm{NO}_{2}$ that is produced by RDX pyrolysis is derived from the rupture of the $\mathrm{N}-\mathrm{NO}_{2}$ bond [47]. However, the $\mathrm{O}-\mathrm{NO}_{2}$ bond rupture is deemed to be the first step, resulting in the release of $\mathrm{NO}_{2}$. The $\mathrm{NO}_{2}$ stagnates in the polymer skeleton and then reacts with the $\mathrm{RO} \bullet$ radical or its decomposition products to produce the $\mathrm{NO}, \mathrm{NO}_{2}, \mathrm{CO}_{2}, \mathrm{CO}, \mathrm{H}_{2} \mathrm{O}$, $\mathrm{N}_{2} \mathrm{O}, \mathrm{HCHO}, \mathrm{HCOOH}$, etc. Finally, the secondary autocatalytic reaction is significantly strengthened.

From the above calculation results, it could be derived that the addition of $\mathrm{CuO}$ and $\mathrm{Al} / \mathrm{CuO}$ nanothermites can reduce the apparent activation energy $\left(E_{\mathrm{a}}\right)$, pre-exponential factor $(A)$, onset temperature $\left(T_{\mathrm{e} 0}\right)$, thermal decomposition peak temperature $\left(T_{\mathrm{p} 0}\right)$, critical thermal ignition temperature $\left(T_{\mathrm{be} 0}\right)$, and the critical temperatures of thermal explosion $\left(T_{\mathrm{bp} 0}\right)$, as compared with single-component $\mathrm{NC}$. This indicates that the $\mathrm{CuO}$ and $\mathrm{Al} / \mathrm{CuO}$ nanothermites can accelerate the thermal decomposition of NC. When compared with the CuO-NC composite system, the $E_{\mathrm{a}}, A, T_{\mathrm{e} 0}, T_{\mathrm{p} 0}$, and $T_{\mathrm{be} 0}$ values of the $\mathrm{Al} / \mathrm{CuO}-\mathrm{NC}$ composite system are all decreased. It indicates that the addition of $\mathrm{Al}$ nanopowders can increase the reactive sites and then accelerate the thermal decomposition of NC because of the high specific surface area of $\mathrm{Al}$ nanopowders or $\mathrm{CuO}$. The physical adsorption might occur between the $\mathrm{Al}$ nanopowders or $\mathrm{CuO}$ and decomposition product of nitrocellulose. This may further effect the autocatalytic decomposition reaction of nitrocellulose.

From Tables 1 and 2, one can find that the $E_{\mathrm{a}}$ values of the thermal decomposition processes of $\mathrm{Al} / \mathrm{CuO}(\mathrm{b})-\mathrm{NC}$ and $\mathrm{Al} / \mathrm{CuO}(\mathrm{f})-\mathrm{NC}$ are $181.1 \mathrm{~kJ} \cdot \mathrm{mol}^{-1}$ and $180.6 \mathrm{~kJ} \cdot \mathrm{mol}^{-1}$, and the $A$ values are $10^{17.4} \mathrm{~s}^{-1}$ and $10^{17.3} \mathrm{~s}^{-1}$, respectively. The little difference of $E_{\mathrm{a}}$ and $A$ between the two nanothermites, indicating that the addition of $\mathrm{Al} / \mathrm{CuO}(\mathrm{b})$ and $\mathrm{Al} / \mathrm{CuO}(\mathrm{f})$ may reduce the thermal decomposition energy barrier of the composites and make it easy to decompose. However, the self-accelerated decomposition temperature $\left(\mathrm{T}_{\mathrm{SADT}}\right)$ of $\mathrm{Al} / \mathrm{CuO}(\mathrm{f})-\mathrm{NC}$ is $152.9^{\circ} \mathrm{C}$, which is $16.4^{\circ} \mathrm{C}$ lower than that of $\mathrm{Al} / \mathrm{CuO}(\mathrm{b})-\mathrm{NC}$. Additionally, the thermal decomposition peak temperature $\left(T_{\mathrm{p} 0}\right)$ of $\mathrm{Al} / \mathrm{CuO}(\mathrm{f})-\mathrm{NC}$ is $7.4^{\circ} \mathrm{C}$ higher than the $\mathrm{Al} / \mathrm{CuO}(\mathrm{b})-\mathrm{NC}$. This shows that the decomposition reaction of $\mathrm{Al} / \mathrm{CuO}(\mathrm{f})-\mathrm{NC}$ is stronger than that of $\mathrm{Al} / \mathrm{CuO}(\mathrm{b})-\mathrm{NC}$, but the time-consumption of the decomposition process of $\mathrm{Al} / \mathrm{CuO}(\mathrm{f})-\mathrm{NC}$ is long. From the results of the critical thermal ignition temperature $\left(T_{\mathrm{be} 0}\right)$ and the critical temperatures of thermal explosion $\left(T_{\mathrm{bp} 0}\right)$, one can get that the $T_{\mathrm{be} 0}$ of $\mathrm{Al} / \mathrm{CuO}(\mathrm{f})-\mathrm{NC}$ is $17.3{ }^{\circ} \mathrm{C}$ lower than the $\mathrm{Al} / \mathrm{CuO}(\mathrm{b})-\mathrm{NC}$, but $T_{\mathrm{pe} 0}$ of $\mathrm{Al} / \mathrm{CuO}(\mathrm{f})-\mathrm{NC}$ is higher than the $\mathrm{Al} / \mathrm{CuO}(\mathrm{b})-\mathrm{NC}$. This indicates that the $\mathrm{Al} / \mathrm{CuO}(\mathrm{f})-\mathrm{NC}$ is more easily ignited, but its decomposition rate is relatively slow. Accordingly, the $\mathrm{Al} / \mathrm{CuO}(\mathrm{f})-\mathrm{NC}$ has a much higher thermal stability than that of the $\mathrm{Al} / \mathrm{CuO}(\mathrm{b})-\mathrm{NC}$.

\section{Conclusions}

Two kinds of nanosize $\mathrm{CuO}$ with different morphologies and sizes were prepared via the hydrothermal method by adjusting the reaction temperature and time. The ultrasonic composite method was used to combine the aluminum nanopowders with the as-prepared bamboo leaf-shaped $\mathrm{CuO}(\mathrm{b})$ and flaky-shaped $\mathrm{CuO}(\mathrm{f})$ to obtain the corresponding $\mathrm{Al} / \mathrm{CuO}(\mathrm{b})$ and $\mathrm{Al} / \mathrm{CuO}(\mathrm{f})$ nanothermites. Based on the non-isothermal decomposition kinetics, the catalytic effect of the different morphologies of $\mathrm{CuO}$ and corresponding nanothermites on the thermal decomposition properties of NC was 
investigated. The additions of $\mathrm{CuO}(\mathrm{b}), \mathrm{Al} / \mathrm{CuO}(\mathrm{b}), \mathrm{CuO}(\mathrm{f})$, and $\mathrm{Al} / \mathrm{CuO}(\mathrm{f})$ do not change the thermal decomposition mechanism of $\mathrm{NC}$. The catalytic effect of $\mathrm{Al} / \mathrm{CuO}$ nanothermites to $\mathrm{NC}$ is better than the $\mathrm{CuO}$, and the $\mathrm{Al} / \mathrm{CuO}(\mathrm{b})-\mathrm{NC}, \mathrm{Al} / \mathrm{CuO}(\mathrm{f})-\mathrm{NC}$ is easier to decompose than the $\mathrm{CuO}(\mathrm{b})-\mathrm{NC}$ and $\mathrm{CuO}(\mathrm{f})-\mathrm{NC}$. The results of compatibility and thermal safety analysis show that the $\mathrm{CuO}$ and $\mathrm{Al} / \mathrm{CuO}$ catalysts have good compatibility with NC, and the catalysts can be used safely. However, the agglomeration of $\mathrm{Al} / \mathrm{CuO}(\mathrm{f})$ is relatively serious. The self-accelerated decomposition temperature $\left(T_{\mathrm{SADT}}\right)$ and the critical thermal ignition temperature $\left(T_{\mathrm{be} 0}\right)$ of $\mathrm{Al} / \mathrm{CuO}(\mathrm{f})-\mathrm{NC}$ are the lowest, while the thermal decomposition peak temperature $\left(T_{\mathrm{p} 0}\right)$ and the critical temperatures of thermal explosion $\left(T_{\mathrm{bp} 0}\right)$ are higher. It shows that the $\mathrm{Al} / \mathrm{CuO}(\mathrm{f})-\mathrm{NC}$ composite material is more easily ignited after being integrated with $\mathrm{NC}$ and $\mathrm{Al} / \mathrm{CuO}(\mathrm{f})$, and the thermal stability during the thermal decomposition process is also better. $\mathrm{The} \mathrm{CuO}(\mathrm{b}), \mathrm{Al} / \mathrm{CuO}(\mathrm{b}), \mathrm{CuO}(\mathrm{f})$, and $\mathrm{Al} / \mathrm{CuO}(\mathrm{f})$ as the catalysts has a wide application prospect in solid propellants.

Author Contributions: Conceptualization, E.Y., N.Z. and H.M.; methodology, E.Y. and N.Z.; validation, Z.Q., H.L., T.A. and F.Z.; formal analysis, S.X. and J.Y.; investigation, E.Y.; writing_original draft preparation, E.Y. and N.Z.; writing-review and editing, N.Z., Z.Q., H.M., H.L. and F.Z.; supervision, F.Z. and N.Z. All authors have read and agreed to the published version of the manuscript.

Funding: This research was supported by the National Natural Science Foundation of China (No. 21473130 and 21905224), Doctoral Scientific Research Foundation of Xi'an University of Technology (No. 109-451117004), Natural Science Basic Research Plan in Shaanxi Province of China (No. 2018JQ2077), and Shaanxi Provincial Department of Education (No. 19JK0595).

Acknowledgments: The authors would like to gratefully thank Luigi T. Deluca for his valuable comments and suggestions to improve the quality of this article.

Conflicts of Interest: The authors declare no conflict of interest.

\section{References}

1. Jia, S.; Wang, Y.; Liu, X.; Zhao, S.; Zhao, W.; Huang, Y.; Li, Z.; Lin, Z. Hierarchically porous CuO nano-labyrinths as binder-free anodes for long-life and high-rate lithium ion batteries. Nano Energy 2019, 59, 229-236. [CrossRef]

2. Tan, G.; Wu, F.; Yuan, Y.; Chen, R.; Zhao, T.; Yao, Y.; Qian, J.; Liu, J.; Ye, Y.; Shahbazian-Yassar, R.; et al. Freestanding three-dimensional core-shell nanoarrays for lithium-ion battery anodes. Nat. Commun. 2016, 7 , 11774. [CrossRef] [PubMed]

3. Nakate, U.T.; Lee, G.H.; Ahmad, R.; Patil, P.; Hahn, Y.-B.; Yu, Y.T.; Suh, E.-k. Nano-bitter gourd like structured $\mathrm{CuO}$ for enhanced hydrogen gas sensor application. Int. J. Hydrog. Energy 2018, 43, 22705-22714. [CrossRef]

4. Du, X.; Zhang, Y.; Si, F.; Yao, C.; Du, M.; Hussain, I.; Kim, H.; Huang, S.; Lin, Z.; Hayat, W. Persulfate non-radical activation by nano-CuO for efficient removal of chlorinated organic compounds: Reduced graphene oxide-assisted and $\mathrm{CuO}\left(\begin{array}{l}0 \\ 0\end{array}\right.$ 1) facet-dependent. Chem. Eng. J. 2019, 356, 178-189. [CrossRef]

5. Wang, L.; Hou, J.; Liu, S.; Carrier, A.J.; Guo, T.; Liang, Q.; Oakley, D.; Zhang, X. CuO nanoparticles as haloperoxidase-mimics: Chloride-accelerated heterogeneous $\mathrm{Cu}$-Fenton chemistry for $\mathrm{H}_{2} \mathrm{O}_{2}$ and glucose sensing. Sensor Actuat. B-CH. 2019, 287, 180-184. [CrossRef]

6. Wang, Z.; Qureshi, N.; Yasin, S.; Mukhin, A.; Ressouche, E.; Zherlitsyn, S.; Skourski, Y.; Geshev, J.; Ivanov, V.; Gospodinov, M.; et al. Magnetoelectric effect and phase transitions in $\mathrm{CuO}$ in external magnetic fields. Nat. Commun. 2016, 7, 10295. [CrossRef]

7. Pandas, H.M.; Fazli, M. Preparation and application of $\mathrm{La}_{2} \mathrm{O}_{3}$ and $\mathrm{CuO}$ nano particles as catalysts for ammonium perchlorate thermal decomposition. Propell. Explos. Pyrot. 2018, 43, 1096-1104. [CrossRef]

8. Dolgachev, V.; Khaneft, A.; Mitrofanov, A. Ignition of organic explosive materials by a copper oxide film absorbing a laser pulse. Propell. Explos. Pyrot. 2018, 43, 992-998. [CrossRef]

9. Hu, Y.; Yang, S.; Tao, B.; Liu, X.; Lin, K.; Yang, Y.; Fan, R.; Xia, D.; Hao, D. Catalytic decomposition of ammonium perchlorate on hollow mesoporous $\mathrm{CuO}$ microspheres. Vacuum 2019, 159, 105-111. [CrossRef]

10. Zhu, Y.; Zhou, X.; Xu, J.; Ma, X.; Ye, Y.; Yang, G.; Zhang, K. In situ preparation of explosive embedded $\mathrm{CuO} / \mathrm{Al} / \mathrm{CL} 20$ nanoenergetic composite with enhanced reactivity. Chem. Eng. J. 2018, 354, 885-895. [CrossRef] 
11. Sharma, J.K.; Srivastava, P.; Singh, G.; Akhtar, M.S.; Ameen, S. Catalytic thermal decomposition of ammonium perchlorate and combustion of composite solid propellants over green synthesized $\mathrm{CuO}$ nanoparticles. Thermochim. Acta 2015, 614, 110-115. [CrossRef]

12. Chowdhury, S.; Sullivan, K.; Piekiel, N.; Zhou, L.; Zachariah, M.R. Diffusive vs explosive reaction at the nanoscale. J. Phys. Chem C 2010, 114, 9191-9195. [CrossRef]

13. Glavier, L.; Nicollet, A.; Jouot, F.; Martin, B.; Barberon, J.; Renaud, L.; Rossi, C. Nanothermite/RDX-based miniature device for impact ignition of high explosives. Propell. Explos. Pyrot. 2018, 42, 308-317. [CrossRef]

14. Yin, Y.; Li, X. Al/CuO composite coatings with nanorods structure assembled by electrophoretic deposition for enhancing energy released. Vacuum 2019, 163, 216-223. [CrossRef]

15. Kim, K.J.; Cho, M.H.; Kim, J.H.; Kim, S.H. Effect of paraffin wax on combustion properties and surface protection of $\mathrm{Al} / \mathrm{CuO}-$ based nanoenergetic composite pellets. Combust. Flame 2018, 198, 169-175. [CrossRef]

16. Courty, L.; Lagrange, J.-F.; Gillard, P.; Boulnois, C. Laser ignition of a low vulnerability propellant based on nitrocellulose: Effects of Ar and $\mathrm{N}_{2}$ surrounding atmospheres. Propell. Explos. Pyrot. 2018, 43, 986-991. [CrossRef]

17. Wei, R.; He, Y.; Zhang, Z.; He, J.; Yuen, R.; Wang, J. Effect of different humectants on the thermal stability and fire hazard of nitrocellulose. J. Therm. Anal. Calorim. 2018, 133, 1291-1307. [CrossRef]

18. Liu, J.; Chen, M. A simplified method to predict the heat release rate of industrial nitrocellulose materials. Appl. Sci. 2018, 8, 910. [CrossRef]

19. Tarchoun, A.F.; Trache, D.; Klapötke, T.M.; Chelouche, S.; Derradji, M.; Bessa, W.; Mezroua, A. A promising energetic polymer from Posidonia oceanica brown algae: Synthesis, characterization, and kinetic modeling. Macromol. Chem. Phys. 2019, 220, 1900358. [CrossRef]

20. Trache, D.; Tarchoun, A.F. Analytical methods for stability assessment of nitrate esters-based propellants. Crit. Rev. Anal. Chem. 2019, 49, 415-438. [CrossRef]

21. Betzler, F.M.; Klapötke, T.M.; Sproll, S. Energetic nitrogen-rich polymers based on cellulose. Cent. Eur. J. Energy Mater. 2011, 8, 157-171.

22. Luo, L.; Jin, B.; Xiao, Y.; Zhang, Q.; Chai, Z.; Huang, Q.; Chu, S.; Peng, R. Study on the isothermal decomposition kinetics and mechanism of nitrocellulose. Polym. Test. 2019, 75, 337-343. [CrossRef]

23. Trache, D.; Maggi, F.; Palmucci, I.; DeLuca, L.T. Thermal behavior and decomposition kinetics of composite solid propellants in the presence of amide burning rate suppressants. J. Therm. Anal. Calorim. 2018, 132, 1601-1615. [CrossRef]

24. Trache, D.; Tarchoun, A.F. Stabilizers for nitrate ester-based energetic materials and their mechanism of action: A state-of-the-art review. J. Mater. Sci. 2018, 53, 100-123. [CrossRef]

25. Chelouche, S.; Trache, D.; Tarchoun, A.F.; Khimeche, K. Effect of organic eutectic on nitrocellulose stability during artificial aging. J. Energy Mater. 2019, 37, 387-406. [CrossRef]

26. Chelouche, S.; Trache, D.; Tarchoun, A.F.; Abdelaziz, A.; Khimeche, K.; Mezroua, A. Organic eutectic mixture as efficient stabilizer for nitrocellulose: Kinetic modeling and stability assessment. Thermochim. Acta 2019, 673, 78-91. [CrossRef]

27. Zhao, N.; Li, J.; Gong, H.; An, T.; Zhao, F.; Yang, A.; Hu, R.; Ma, H. Effects of $\alpha-\mathrm{Fe}_{2} \mathrm{O}_{3}$ nanoparticles on the thermal behavior and non-isothermal decomposition kinetics of nitrocellulose. J. Anal. Appl. Pyrol. 2016, 120, 165-173. [CrossRef]

28. Guo, Y.; Zhao, N.; Zhang, T.; Gong, H.; Ma, H.; An, T.; Zhao, F.; Hu, R. Compatibility and thermal decomposition mechanism of nitrocellulose $/ \mathrm{Cr}_{2} \mathrm{O}_{3}$ nanoparticles studied using DSC and TG-FTIR. RSC Adv. 2019, 9, 3927-3937. [CrossRef]

29. Chelouche, S.; Trache, D.; Tarchoun, A.F.; Abdelaziz, A.; Khimeche, K. Compatibility assessment and decomposition kinetics of nitrocellulose with eutectic mixture of organic stabilizers. J. Energy Mater. 2020, 38, 48-67. [CrossRef]

30. Trache, D.; Tarchoun, A.F.; Chelouche, S.; Khimeche, K. New insights on the compatibility of nitrocellulose with aniline-based compounds. Propell. Explos. Pyrot. 2019, 44, 970-979. [CrossRef]

31. Yousef, M.A.; Hudson, M.K.; Berry, B.C. Study on the compatibility of azo-tetrazolate high-energy materials using DSC. J. Therm. Anal. Calorim. 2018, 133, 1481-1490. [CrossRef]

32. Huang, H.; Shi, Y.; Yang, J.; Li, B. Compatibility study of dihydroxylammonium 5,5'-bistetrazole-1,1'-diolate (TKX-50) with some energetic materials and inert materials. J. Energy Mater. 2015, 33, 66-72. [CrossRef] 
33. Liu, Z. Thermal Analyses for Energetic Materials; National Defense Industry Press: Beijing, China, 2008; pp. 21-22.

34. An, T.; Zhao, F.; Pei, Q.; Xiao, L.; Xu, S.; Gao, H.; Xing, X. Preparation, characterization and combustion catalytic activity of nanopartical super thermites. Chin. J. Inorg. Chem. 2011, 27, 231-238.

35. Zhao, F.; Yi, J.; An, T.; Wang, Y.; Hong, W. Combustion Catalysts for Solid Propellant; National Defense Industry Press: Beijing, China, 2016; pp. 90-120.

36. Prentice, D.; Pantoya, M.L.; Clapsaddle, B.J. Effect of nanocomposite synthesis on the combustion performance of a ternary thermite. J. Phys. Chem. B 2005, 109, 20180-20185. [CrossRef] [PubMed]

37. Shende, R.; Subramanian, S.; Hasan, S.; Apperson, S.; Thiruvengadathan, R.; Gangopadhyay, K.; Gangopadhyay, S.; Redner, P.; Kapoor, D.; Nicolich, S.; et al. Nanoenergetic composites of CuO nanorods, nanowires, and Al-nanoparticles. Propell. Explos. Pyrot. 2008, 33, 122-130. [CrossRef]

38. Criado, J.M.; Sánchez-Jiménez, P.E.; Pérez-Maqueda, L.A. Critical study of the isoconversional methods of kinetic analysis. J. Therm. Anal. Calorim. 2008, 92, 199-203. [CrossRef]

39. Ma, H.; Song, J.; Hu, R.; Pan, Q.; Wang, Y. Non-isothermal decomposition kinetics, thermal behavior and computational detonation properties on 4-amino-1,2,4-triazol-5-one (ATO). J. Anal. Appl. Pyrol. 2008, 83, 145-150. [CrossRef]

40. Vyazovkin, S.; Burnham, A.K.; Criado, J.M.; Pérez-Maqueda, L.A.; Popescu, C.; Sbirrazzuoli, N. ICTAC Kinetics Committee recommendations for performing kinetic computations on thermal analysis data. Thermochim. Acta 2011, 520, 1-19. [CrossRef]

41. Trache, D. Comments on "Thermal degradation behavior of hypochlorite-oxidized starch nanocrystals under different oxidized levels". Carbohydr. Polym. 2016, 151, 535-537. [CrossRef]

42. Sánchez-Jiménez, P.E.; Pérez-Maqueda, L.A.; Perejón, A.; Criado, J.M. Nanoclay nucleation effect in the thermal stabilization of a polymer nanocomposite: A kinetic mechanism change. J. Phys. Chem. C 2012, 116, 11797-11807. [CrossRef]

43. Zhang, T.; Hu, R.; Xie, Y.; Li, F. The estimation of critical temperatures of thermal explosion for energetic materials using non-isothermal DSC. Thermochim. Acta 1994, 244, 171-176.

44. Yi, J.; Zhao, F.; Wang, B.; Liu, Q.; Zhou, C.; Hu, R.; Ren, Y.; Xu, S.; Xu, K.; Ren, X. Thermal behaviors, nonisothermal decomposition reaction kinetics, thermal safety and burning rates of BTATz-CMDB propellant. J. Hazard. Mater. 2010, 181, 432-439. [CrossRef] [PubMed]

45. Muravyev, N.V.; Kiselev, V.G. Cheaper, faster, or better: Are simple estimations of safety parameters of hazardous materials reliable? J. Hazard. Mater. 2017, 334, 267-270. [CrossRef] [PubMed]

46. Hu, R.; Gao, S.; Zhao, F.; Shi, Q.; Zhang, T.; Zhang, J. Thermal Analysis Kinetics, 2nd ed.; Science Press: Beijing, China, 2008; pp. 148-167.

47. Peng, L.; Yao, Q.; Wang, J.; Li, Z.; Zhu, Q.; Li, X. Pyrolysis of RDX and its derivatives via reactive molecular dynamics simulations. Acta Phys. Chim. Sin. 2017, 33, 745-754. 